\title{
パルス性地震動入力時の超高層集合住宅における負傷予測に向けた人体応答評価 EVALUATION OF HUMAN RESPONSES TOWARD INJURY PREDICTION IN SUPER HIGH-RISE
RESIDENTIAL BUILDINGS EXCITED BY PULSE-LIKE GROUND MOTIONS
}

唐 津 啓 樹*1, 肥田剛 典*2, 永 野 正 行*3

Hiroki KARATSU, Takenori HIDA and Masayuki NAGANO

\begin{abstract}
When a large pulse-like ground motion strikes in urban areas, significant structural damages may occur to super-high-rise residential buildings along with human injuries or fatalities. Herein, to evaluate human injury, human responses were investigated in super-high-rise residential buildings using the Ricker wavelet as the pulse-like ground motion. Using nonlinear seismic response analysis models of super-high-rise RC buildings and those of the human body, the variation in the maximum displacement of the center of pressure $(\mathrm{CoP})$ and head velocity was examined based on the predominant periods and amplitude level of the input seismic waves.
\end{abstract}

Keywords : Human model, Super high-rise residential building, Pulse-like ground motion, Ricker wavelet, Human response 人体モデル, 超高層集合住宅, パルス性地震動, リッカー波, 人体応答

\section{1. はじめに}

我が国では 1995 年兵庫県南部地震, 2016 年熊本地震などの内陸 地殼内の地震が発生し, 断層近傍では大振幅パルスを有する地震動 (以降，パルス性地震動）が観測されている。特に，2016年熊本地 震では，震源のごく近傍で周期 3 秒前後の長周期パルスを有する地 震動も観測された。現在国内では多数の超高層集合住宅が建設され ており ${ }^{20)}$ ，仮にこのようなパルス性地震動が建物に入力した場合， 構造被害とともに人的被害を含む室内被害を与えることが懸念され る。過去の被害地震では, 建物被害だけでなく, 多くの人的被害が 報告されている(例えば2)-6)。地震時のけがの要因として, 割れたガラス や食器による切傷等の他, 家具の転倒による打撲, 人間の転倒や物 への衝突による打撲や骨折等が報告されている。超高層建物の建物 応答特性の把握とともに, 超高層建物に居住する人体の応答特性を 把握することは, 室内の人的被害を予測し, 居住者の安全性や震災 後の生活継続性を評価する上で重要となる。

パルス性地震動に対する建物応答に関しては, 過去に多数の検討 例えば 7)-10)が行われている。小山・永野 ${ }^{11)}$ はパルス性地震動として Ricker 波を速度波とし, その擬似速度応答スペクトルを利用して RC 造建物の非線形応答特性を整理した。小山ら ${ }^{12)}$ はこの Ricker 波と 3 次元立体フレームモデルを用い, 入力波の擬似速度応答スペクトル の変化と最大層間変形角の関係性を示した。村田ら $\left.{ }^{13}\right)$ はパルス性地 震動の応答スペクトルの卓越周期, 最大值に着目して応答結果を基 準化し，観測記録の応答スペクトルから最大建物応答を予測するこ
とが可能な形で結果を取りまとめた。ただし, これらの研究は構造 躯体の応答評価把握に着目しており，建物内での負傷などの人的被 害の評価は対象外となる。

これまでに，地震時における人的被害を評価した研究が行われて いる例えば 14-17)が，それらの研究では地震時における人体の挙動が考 慮されていない。これに対し, 肥田ら ${ }^{18)}$, 19) は地震時の人的被害評価 に向けた人体の地震応答解析モデル (以降, 人体モデル) を構築し た。伊東ら ${ }^{20)}$ はこの人体モデルを用いて被震時の人体の応答 (以降, 人体応答）と床応答の関係を明らかにし，人間の地震時負傷評価手 法を提案した。肥田ら ${ }^{21}$ はさらに, 超高層建物の地震応答解析によ り得られる各階の床応答を人体モデルに入力し，同建物内において 人体の頭部が周囲の壁等に衝突した際の負傷評価法を提案した。

これらの研究で提案された負傷評価法では，建物の床応答が与え られていることが前提となる。しかし，建物の地震応答解析モデル が得られていない場合や，建物内に強震計が設置されていない場合 には，地震時の床応答を得ることは困難となる。そのため，地震発 生後に迅速に建物内の人的被害を推定するためには，建物の地震応 答解析を介さず，地表面もしくは建物基部で得られた強震記録のみ から直接建物内の人間の負傷を評価できることが望ましい。

以上の背景を踏まえ, 本研究では, パルス性地震動として振幅レ ベルおよび卓越周期を簡便に調整できる Ricker 波を利用する。平均 的な動的特性を反映した超高層建物モデル 22) の地震応答解析から 得られた各階の床応答を人体モデルに入力し, 超高層建物内におけ
$\mathrm{JFE}$ シビル(侏）(元東京理科大学)

茨城大学大学院理工学研究科都市システム工学専攻 准教授、 博士 (工学)

3 東京理科大学理工学部建築学科 教授・博士 (工学)
JFE Civil Engineering \& Construction Corp. (Former, Tokyo University of Science) Assoc. Prof., Graduate School of Science and Engineering, Ibaraki University, Dr.Eng.

Prof., Dept. of Architecture, Tokyo University of Science, Dr.Eng. 
る人間の負傷予測に向けた人体応答を評価する。この際, パルス性 地震動の応答スペクトルの卓越周期に着目して応答結果を基準化し, 応答スペクトルの最大值から建物モデルを介さずに最大人体応答お よび負傷可能性を評価する形で結果をまとめる。次に, 超高層集合 住宅居住者を対象とした実地震時の摇れの体感に関するアンケート 調查結果や, 過去の地震で観測されたパルス性地震動を入力したと きの人体応答の検討を通じ, Ricker 波入力時の応答による最大人体 応答結果を検証する。

\section{2. 人体の非線形地震応答解析モデルと負傷評価法}

\section{1 人体の非線形地震応答解析モデルの概要}

本研究で用いる人体モデルを Fig. 1 に示す。本解析モデルは台車 型二重倒立振子 ${ }^{21)}$ に基づいており, 人体の立位時における足の踏み 出しを考慮した前後方向の地震時挙動を求めるものである。

このモデルの非線形運動方程式は次式で得られる ${ }^{21)}$ 。

$$
\begin{aligned}
d_{1}\left\{\ddot{\xi}(t)+\ddot{\xi}_{0}(t)\right\}+ & d_{2} \ddot{\theta}_{1}(t) \cos \theta_{1}(t)+d_{3} \ddot{\theta}_{2}(t) \cos \theta_{2}(t)+\mu_{c} \dot{\xi}(t)= \\
& d_{2}\left\{\dot{\theta}_{1}(t)\right\}^{2} \sin \theta_{1}(t)+d_{3}\left\{\dot{\theta}_{2}(t)\right\}^{2} \sin \theta_{2}(t)+f_{c}(t)
\end{aligned}
$$

$d_{2} \cos \theta_{1}(t)\left\{\ddot{\xi}(t)+\ddot{\xi}_{0}(t)\right\}+d_{4} \ddot{\theta}_{1}(t)+d_{5} \cos \left\{\theta_{1}(t)-\theta_{2}(t)\right\} \ddot{\theta}_{2}(t)=$

$$
d_{7} \sin \theta_{1}(t)-d_{5}\left\{\dot{\theta}_{2}(t)\right\}^{2} \sin \left\{\theta_{1}(t)-\theta_{2}(t)\right\}-\tau(t)
$$

$d_{3} \cos \theta_{2}(t)\left\{\ddot{\xi}(t)+\ddot{\xi}_{0}(t)\right\}+d_{5} \cos \left\{\theta_{1}(t)-\theta_{2}(t)\right\} \ddot{\theta}_{1}(t)+d_{6} \ddot{\theta}_{2}(t)=$

$$
d_{5}\left\{\dot{\theta}_{1}(t)\right\}^{2} \sin \left\{\theta_{1}(t)-\theta_{2}(t)\right\}+d_{8} \sin \theta_{2}(t)+\tau(t)
$$

ここに, $\xi(t)$ は時刻 $t$ における床に対する台車の相対変位, $\xi_{0}(t)$ は床 の絶対変位, $\theta_{1}(t)$ および $\theta_{2}(t)$ は下および上の振子の鉛直線に対寸る 角度, $f_{\mathrm{c}}(t)$ は台車に加える制御力, $\tau(t)$ は上下の振子を繋ぐヒンジ $($ 腰 部）に加えるトルク， $\mu_{\mathrm{c}}$ は台車の粘性減衰係数である。式(1)〜(3)の $d_{1} \sim d_{8}$ は次式で表される ${ }^{23)}$ 。

$$
\begin{array}{ll}
d_{1}=m_{1}+m_{2}+m_{c} & d_{2}=m_{1} l_{1}+m_{2} L_{1} \\
d_{3}=m_{2} l_{2} & d_{4}=J_{1}+m_{1} l_{1}^{2}+m_{2} L_{1}^{2} \\
d_{5}=m_{2} l_{2} L_{1} & d_{6}=J_{2}+m_{2} l_{2}^{2} \\
d_{7}=\left(m_{1} l_{1}+m_{2} L_{1}\right) g & d_{8}=m_{2} l_{2} g
\end{array}
$$

$m_{1}, m_{2}$ および $m_{\mathrm{c}}$ はそれぞれ下の振子, 上の振子および台車の質量 であり， $J_{1}$ および $J_{2}$ は下および上の振子の慣性モーメントである。 また， $l_{1}$ および $l_{2}$ は下および上の振子の下端から質量中心までの長 さ, $L_{1}$ および $L_{2}$ は下および上の振子の全長, $g$ は重力加速度である。 人体モデルのパラメータをTable 1に, フィードバックゲインを Table 2 に示す。

人間の立位時のバランス制御のために重要な床反力中心 (Center of Pressure, $\mathrm{CoP}$ )の変位(以下, $\mathrm{CoP}$ 変位)は $\xi(t)$ に対応する。

\section{2 頭部速度と頭部傷害基準值による負傷可能性評価}

地震時の人的被害として人間の転倒・転落, 家具との衝突が挙げ られ，人体頭部の障害物への衝突が致命的な負傷に繋がりやすいと 考えられる。このことから, 本研究では自動車や事故衝撃からの保 護基準としても用いられている頭部障害基準 (Head Injury Criterion, $\mathrm{HIC}^{24), 25)}$ )より人間の負傷予測に向けた人体応答を評価することと する。文献 20)によれば, HIC は人体頭部の衝突直前の速度 $V_{\text {head }}$ を 用いて，次式で表すことが出来る。

$$
H I C=\left(t_{2}-t_{1}\right)\left\{\frac{V_{\text {head }}}{g \Delta t}(1+e)\right\}^{2.5}
$$

反発係数 $e$ および衝突時間 $\Delta t$ は文献 20) と同様に設定した。また, 文 献 20)に基づき, 本研究では $V_{\text {head }}$ に人体モデルから求められる頭部 の最大速度 $(\mathrm{cm} / \mathrm{s})$ を用いる。頭部速度 $V_{\text {head }}$ は, 式(1) (3)に示した人 体モデルにより算出した $\dot{\xi}(t), \dot{\theta}_{1}(t), \theta_{1}(t), \dot{\theta}_{2}(t)$ おび $\theta_{2}(t)$ を用 いて次式で求められる。

$$
V_{\text {head }}(t)=\dot{\xi}(t)+\dot{\theta}_{1}(t) L_{1} \cos \theta_{1}(t)+\dot{\theta}_{2}(t) L_{2} \cos \theta_{2}(t)
$$

$50 \%$ の確率で起こる頭部の負傷度と HIC 值, 最大頭部速度の対応

\begin{tabular}{|c|c|c|c|c|c|c|c|c|c|c|c|}
\hline$m_{1}(\mathrm{~kg})$ & $m_{2}(\mathrm{~kg})$ & $m_{\mathrm{c}}(\mathrm{kg})$ & $L_{1}(m)$ & $L_{2}(m$ & $I_{1}(\mathrm{~m})$ & $I_{2}(\mathrm{~m}) \quad J$ & $J_{1}\left(\mathrm{kgm}^{2}\right)$ & $J_{2}\left(\mathrm{kgm}^{2}\right)$ & $\mu_{\mathrm{c}}(\mathrm{Ns} / \mathrm{m})$ & $L(\mathrm{~s})$ & $g\left(\mathrm{~m} / \mathrm{s}^{2}\right)$ \\
\hline 16.7 & 38.6 & 1.68 & 0.82 & 0.78 & 0.453 & 0.301 & 5.55 & 3.50 & 10000 & 0.1 & 9.8 \\
\hline \multicolumn{12}{|c|}{ Table 2} \\
\hline & & $k_{f \xi}(\mathrm{N} / \mathrm{m})$ & \multicolumn{2}{|c|}{$k_{f \theta 1}(\mathrm{~N} / \mathrm{rad})$} & $k_{f \theta 2}(\mathrm{~N} / \mathrm{rad})$ & $k_{f \xi}(\mathrm{Ns} / \mathrm{m})$ & \multicolumn{2}{|c|}{$k_{f \theta 1}(\mathrm{Ns} / \mathrm{rad})$} & $k_{f \dot{\theta} 2}(\mathrm{Ns} / \mathrm{rad})$ & & \\
\hline & & 175 & \multicolumn{2}{|c|}{-39700} & -24000 & -12900 & \multicolumn{2}{|c|}{-12300} & -4530 & & \\
\hline & & $k_{T \zeta}(\mathrm{N} / \mathrm{m})$ & \multicolumn{2}{|c|}{$k_{r \theta 1}(\mathrm{Nm} / \mathrm{rad})$} & $k_{r \theta 2}(\mathrm{Nm} / \mathrm{rad})$ & $k_{T \bar{\xi}}(\mathrm{Ns})$ & \multicolumn{2}{|c|}{$k_{r \theta 11}(\mathrm{Nms} / \mathrm{rad})$} & $k_{\mathrm{T} \dot{ } \theta}(\mathrm{Ns} / \mathrm{rad})$ & & \\
\hline & & -12.8 & \multicolumn{2}{|c|}{-66.5} & 186 & -14.3 & \multicolumn{2}{|c|}{-22.6} & 24.8 & & \\
\hline
\end{tabular}
関係 ${ }^{20)}$ を Table 3 に示す。本研究ではこれを参考に, 人体の最大頭 部速度を用いて人間の負傷可能性を評価することとする。この設定 は人体の頭部が最大速度で剛体の面に衝突した場合のものであり, 実地震時における実際の挙動に比して過大評価となる可能性がある ことに注意が必要である。

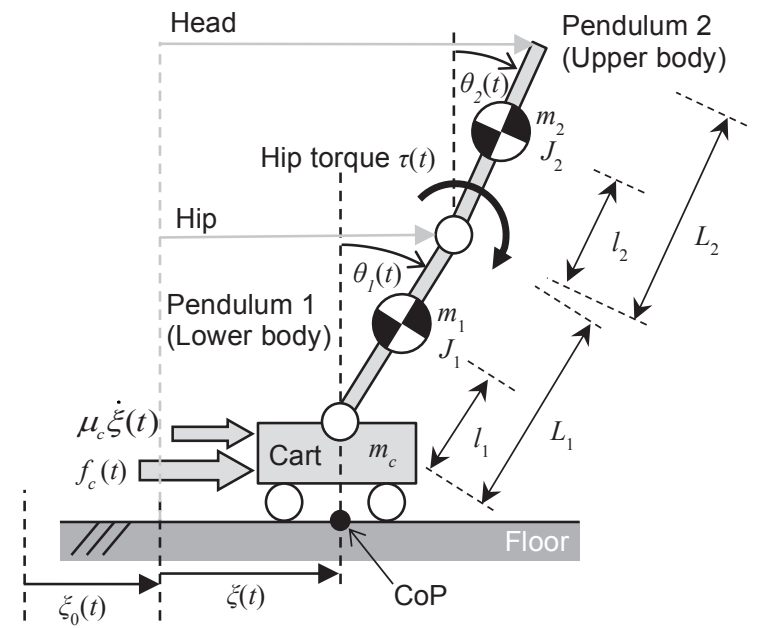

Fig. 1 Seismic response analysis model of human body based on cart-type double inverted pendulum ${ }^{21)}$
Table 1 Parameter of cart-type double inverted pendulum model ${ }^{20}$ )
Table 3 HIC and head velocity corresponding to head injury level ${ }^{20}$ )

\begin{tabular}{|c|c|c|}
\hline Head injury level & $\begin{array}{c}\text { HIC } \\
(\mathrm{p}=50 \%)\end{array}$ & $\begin{array}{c}\text { Head velocity } \\
(\mathrm{cm} / \mathrm{s})\end{array}$ \\
\hline $\begin{array}{c}\text { Minor(head injury without } \\
\text { disturbance of consciousness) }\end{array}$ & 331 & 205 \\
\hline $\begin{array}{c}\text { Moderate } \\
\text { (skull fracture) }\end{array}$ & 593 & 259 \\
\hline $\begin{array}{c}\text { Critical } \\
\text { (cerebral contusion) }\end{array}$ & 1848 & 408 \\
\hline $\begin{array}{c}\text { Fatal } \\
\text { (death) }\end{array}$ & 2175 & 435 \\
\hline
\end{tabular}


3 パルス性地震動に対する人体応答の基本特性

\subsection{Ricker 波の卓越周期，振幅の設定}

パルス性地震動に対する人体応答の基本特性を検討するために人 体モデルにパルス波を入力する。本研究ではパルス波として Ricker 波を速度波として用いる ${ }^{11)}$ 。卓越周期及び振幅レ心゙ルによる変化を 検討するため，以下の 2 パターンのパルス波群を用意した。

(1) 擬似変位応答スペクトル $p S d(h=5 \%)$ の最大值 $p S d_{\max }$ を $10 \mathrm{~cm}, 20 \mathrm{~cm}, 30 \mathrm{~cm}$ に設定し, 卓越周期 $T_{\mathrm{p}}$ を $0.1 \mathrm{~s}$ ずつ変化させた Ricker 波。

(2) 擬似速度応答スペクトル $p S v \quad(h=5 \%)$ の最大值 $p S v$ max $50 \mathrm{~cm} / \mathrm{s}, 100 \mathrm{~cm} / \mathrm{s}, 150 \mathrm{~cm} / \mathrm{s}$ に設定し, 卓越周期 $T_{\mathrm{p}}$ を $0.1 \mathrm{~s}$ ずつ変 化させた Ricker 波。

入力波の継続時間は $40 \mathrm{~s}$ とし, 最大速度の発生時刻は $10 \mathrm{~s}$ とした。 速度波である Ricker 波を時間に関して微分し，それを加速度波形と して人体モデルに入力した。 $p S d_{\max }$ が $20 \mathrm{~cm}$ となる速度及び加速度 の時刻歴波形と $p S d(h=5 \%)$ を Fig. 2 に示す。Fig. 3 に $p S d_{\text {max }}=20(\mathrm{~cm})$ の $T_{\mathrm{p}}=1.0(\mathrm{~s}), 2.0(\mathrm{~s}), 3.0(\mathrm{~s})$ のときの人体モデルの時刻歴応答波形及 び振幅レベル $p S d_{\max }$ を変化させた最大 $\mathrm{CoP}$ 変位, 最大頭部速度を示 す。入力波の $p S d_{\max }$ が一定の場合, 最大頭部速度は卓越周期 $0.1(\mathrm{~s})$ か ら単調減少する。一方, 最大 $\mathrm{CoP}$ 変位は卓越周期 $T_{\mathrm{p}}=0.5(\mathrm{~s})$ 以上の 周期帯で同振幅レベルとなる。最大 $\mathrm{CoP}$ 変位及び最大頭部速度とも に, $p S d_{\max }$ が変化しても概初同様の変化を見せる。

また，Fig. 4 にS $v_{\text {max }}$ が $100 \mathrm{~cm} / \mathrm{s}$ となる速度及び加速度の時刻歴 波形と $p S v(h=5 \%)$, Fig. 5 に $p v_{\text {max }}=100(\mathrm{~cm} / \mathrm{s})$ の $T_{\mathrm{p}}=1.0(\mathrm{~s}), 2.0(\mathrm{~s})$, $3.0(\mathrm{~s})$ のときの人体モデルの時刻歴応答波形及び振幅レベル $p S v_{\text {max }}$

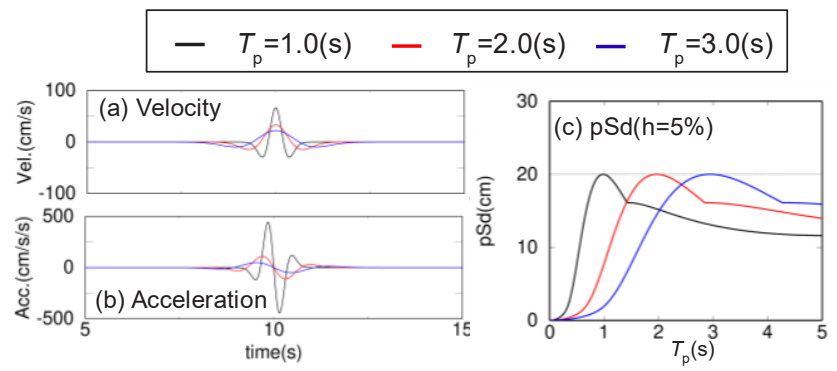

Fig. 2 Waveforms of Ricker wavelets with constant $p S d_{\text {max }}$

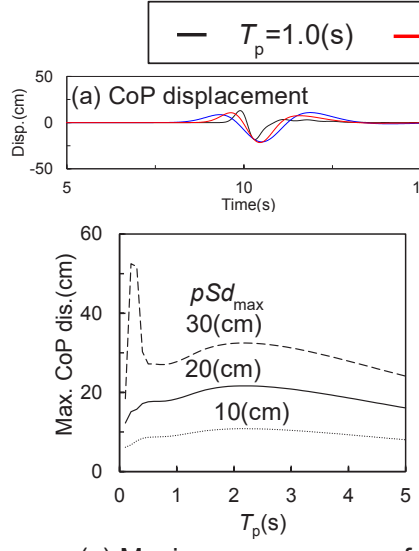

(c) Maximum responses of CoP displacement
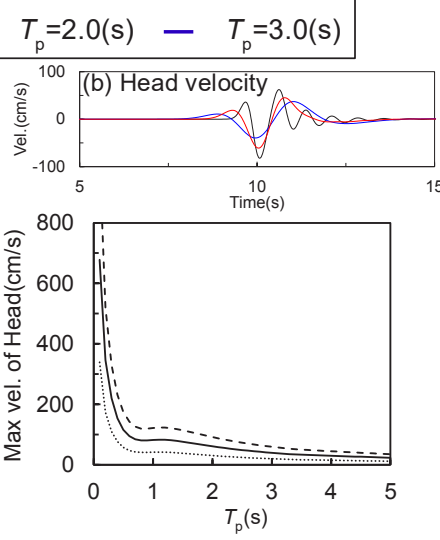

(d) Maximum responses of Head velocity
Fig. 3 Human responses by Ricker wavelet with constant $p S d_{\text {max }}$
を変化させた最大 $\mathrm{CoP}$ 変位, 最大頭部速度を示す。入力波の $p S v_{\text {max }}$ が一定の場合, 最大 $\mathrm{CoP}$ 変位は卓越周期が大きくなるほど大きくな る。一方, 最大頭部速度は $T_{\mathrm{p}}=1.0(\mathrm{~s})$ 以上の周期帯で同振幅レベルと なる。最大 $\mathrm{CoP}$ 変位及び最大頭部速度ともに, $p S v_{\max }$ が変化しても 概补同様の変化を見せる。

後述するように, 本研究で対象とする超高層建物の固有周期が 1 秒以上であることと各応答の整理のしやすさを鑑み, 次節以降, $\mathrm{CoP}$ 変位に着目する際には $p S d_{\max }$ を一定にした Ricker 波を用い，頭部速 度に着目する際は $p S v_{\text {max }}$ を一定にした Ricker 波を用いた。

\section{2 超高層 RC 造建物のモデル化}

パルス性地震動に対する建物応答の基本特性を検討するために卓 越周期を変化させた Ricker 波を建物モデルに入力した時の建物の非 線形応答を検討寸る。建物は超高層 RC 造建物と寸る。本研究では 文献 22)の建物解析モデルを使用する。解析モデルはせん断型多質 点系モデルで，各層の復元力特性は剛性低減型卜リリニアモデルで ある。層剛性，耐力等の骨格特性は，20 階もしくは軒高 $60 \mathrm{~m}$ 以上の 既存の超高層 $\mathrm{RC}$ 造建物 39 棟の構造特性の平均的な特性に基づき 構築した。文献 22)を参考に, 階高を $3 \mathrm{~m}$, 建物の階数を $N$ として, 建物の 1 次固有周期 $T_{0}=0.06 N(\mathrm{~s})$ とする。基準階床面積 $A_{0}=900\left(\mathrm{~m}^{2}\right)$, 第三剛性は初期剛性の 0.1 倍と寸る。減衰は瞬間剛性比例型とし, 2016 年熊本地震時のシミュレーション解析 ${ }^{22)}$ を参考に 1 次固有周 期に対し減衰定数 $h=0.02$ とする。

$p S d_{\max }=20(\mathrm{~cm})$ における $T_{p}=1.0,2.0,3.0(\mathrm{~s})$ のときの Ricker 波入 力時における建物各階の床応答の最大絶対変位 (Peak floor displacement, PFD), 最大絶対速度(Peak floor velocity, PFV)および最

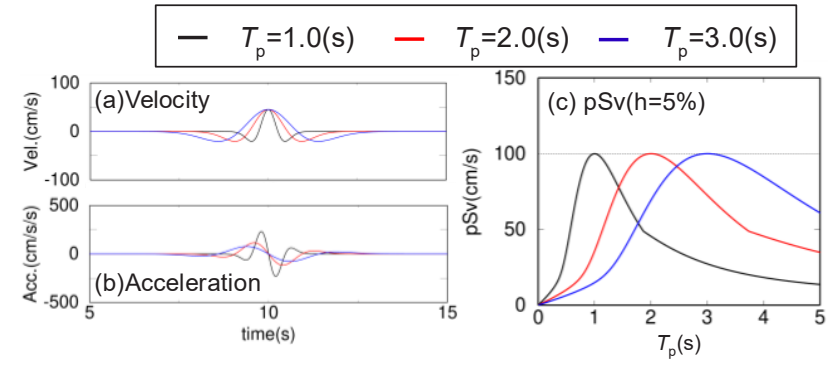

Fig. 4 Waveforms of Ricker wavelets with constant $p S v_{\max }$

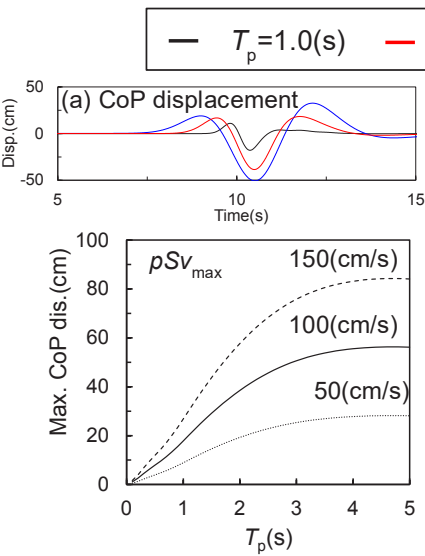

(c) Maximum responses of CoP displacement
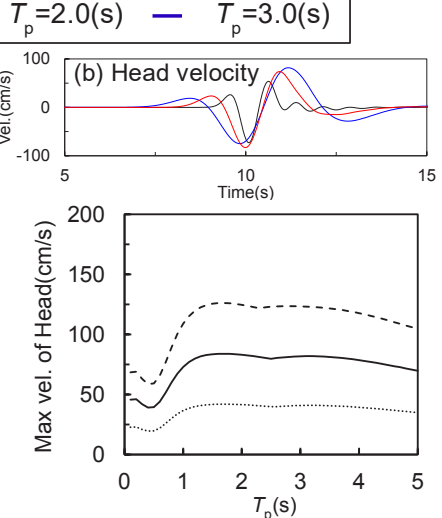

(d) Maximum responses of Head velocity

Fig. 5 Human responses by Ricker wavelet with constant $p S v_{\max }$ 


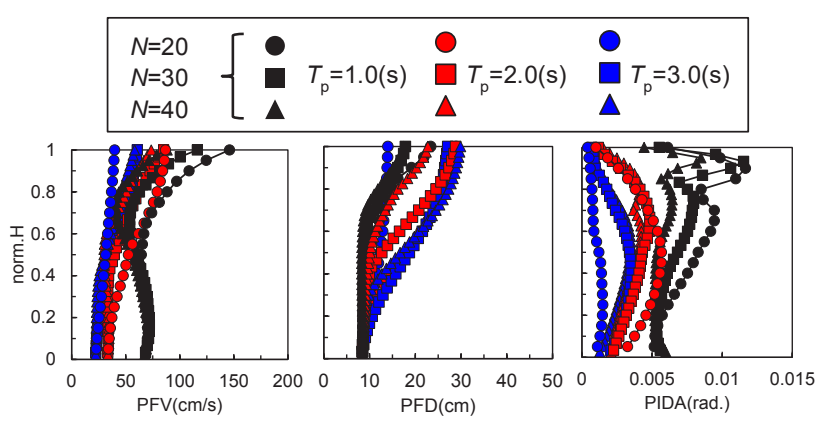

Fig. 6 Height-wise distribution of seismic responses of buildings by Ricker wavelet $\left(p S d_{\max }=20(\mathrm{~cm})\right)$
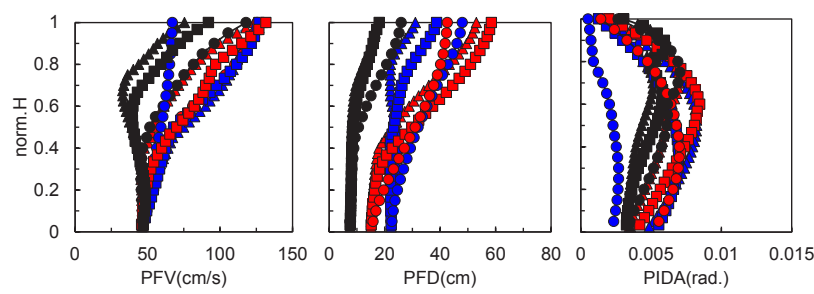

Fig. 7 Height-wise distribution of seismic responses of buildings by Ricker wavelet $\left(p S v_{\max }=100(\mathrm{~cm} / \mathrm{s})\right)$

大層間変形角 (peak inter-story drift angle, PIDA) の高さ分布を Fig. 6 に示す。また, $p S v_{\max }=100(\mathrm{~cm} / \mathrm{s})$ における同様の解析結果を Fig. 7 に 示す。なお, 建物階数は $N=20,30,40$ とし, 各層の高さを建物高さ で除した基準化高さ（norm.H）を縦軸とした。いずれのケースでも PFD および PFV は低層階から高層階へ向けて大きくなる傾向にあ る。 $p S d_{\max }$ が $20(\mathrm{~cm}), T_{\mathrm{p}}=1.0(\mathrm{~s})$ のケースの高層階の一部で PIDA が $1 / 100 \mathrm{rad}$ を上回るが, 全体的に 1/300〜1/100 rad の最大層間変形角と なっている。

\section{3 超高層 $\mathrm{RC}$ 造建物の床応答による人体応答}

次にパルス性地震動に対する超高層建物内の人体応答を評価する ために前節の建物モデルの地震応答解析により各階の床応答を求め, これらを人体モデルに入力する。

$p S d_{\max }=20(\mathrm{~cm}), T_{\mathrm{p}}=1.0(\mathrm{~s}), \quad N=20$ における各階の床応答加速度波 形を Fig. 8 に, $p S d_{\max }=20(\mathrm{~cm}), T_{\mathrm{p}}=1.0(\mathrm{~s}), N=20$ における Ricker 波 入力時の基準化高さ $0.25,0.5,0.75$ および 1.0 の人体モデルのスナ ップショットを Fig. 9 に示す。Ricker 波の最大速度発生時刻の $10 \mathrm{~s}$ 付近から CoP と頭部が左右に大きく変位し, 頭部一腰部一 CoP の位 置関係が「く」の字型となりバランスを保っている。また, CoP 変 位および頭部変位は建物応答の PFD および PFV と同様に低層階よ りも高層階で大きくなる。

パルス性地震動に対する超高層建物内の人間の応答と挙動の全体 的な傾向を検討するため, Ricker 波入力時の超高層建物内における 人体モデルの最大 $\mathrm{CoP}$ 変位および最大頭部速度と, Ricker 波の卓越 周期 $T_{\mathrm{p}}$ の関係を Fig. 10 に示す。なお，ここでは $p S v_{\text {max }}=100(\mathrm{~cm} / \mathrm{s})$ および $p S d_{\max }=20(\mathrm{~cm})$ とし, 基準化高さ $0.5,1.0$ における結果を示 す。建物への入力波の卓越周期 $T_{\mathrm{p}}$ は $0.1 \mathrm{~s}$ ずつ $0.1 \mathrm{~s} \sim 5.0 \mathrm{~s}$ の範囲で 変化させ, 建物階数 $N=20,30,40$ とした。また, Ricker 波との比較 のため建築性能基準推進協会 ${ }^{26)}$ により提供されている El Centro NS, Taft EW, Hachinohe NS を既往波として, $p S v_{\max }=100(\mathrm{~cm} / \mathrm{s})$ および $p S d_{\max }=20(\mathrm{~cm})$ とした超高層建物内における人体モデルの最大 $\mathrm{CoP}$ 変位および最大頭部速度も図中に併記した。さらに, 建物の弾性時
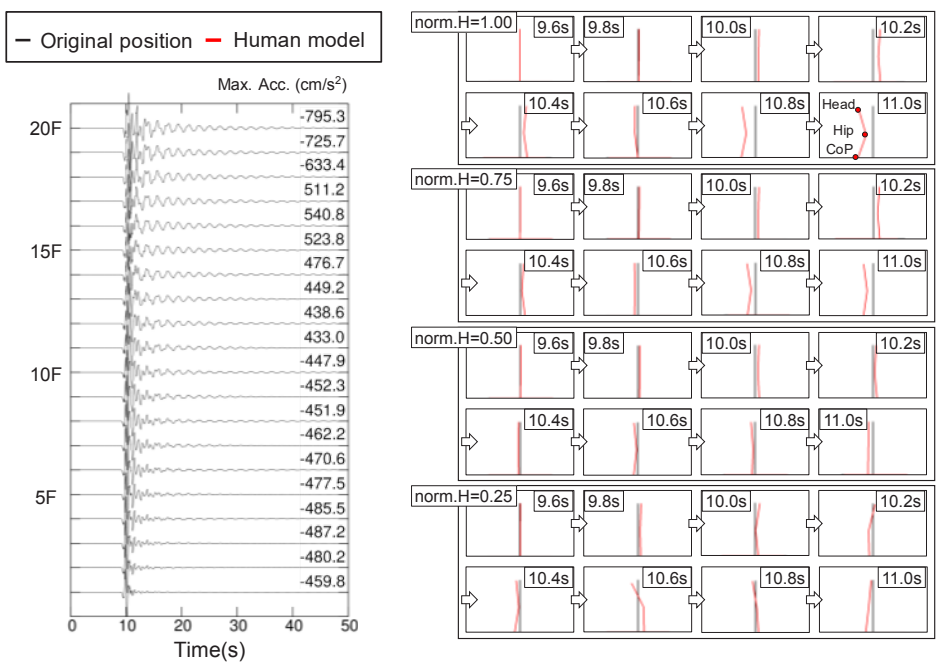

Fig. 8 Floor response acceleration $\left(p S d_{\max }=20(\mathrm{~cm}), T_{\mathrm{p}}=1.0(\mathrm{~s}), N=20\right)$

Fig. 9 Snapshots of human model $\left(p S d_{\max }=20(\mathrm{~cm}), T_{\mathrm{p}}=1.0(\mathrm{~s}), N=20\right)$
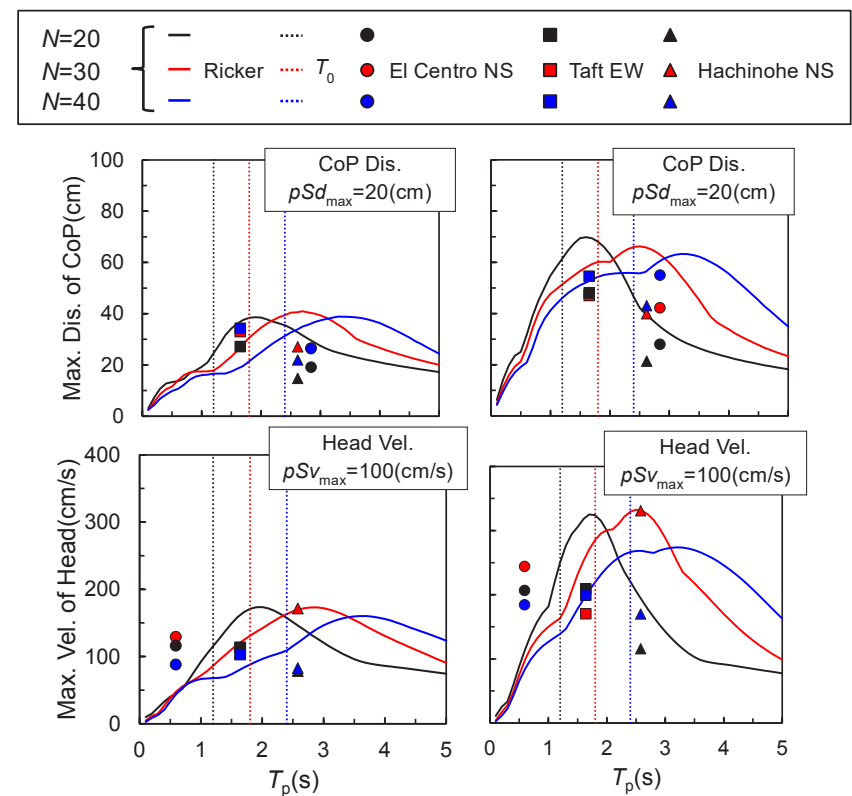

(a) norm. $\mathrm{H}=0.50$

(b) norm. $\mathrm{H}=1.00$

Fig. 10 Maximum Human responses in three types of buildings

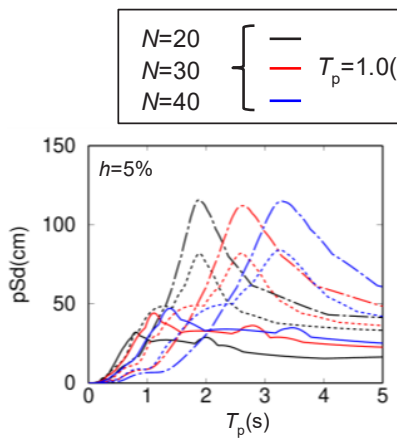

(a) $p S d(\mathrm{~h}=5 \%)$

\section{$\ldots . . . T_{p}=2.0(\mathrm{~s}) \stackrel{---}{--} T_{\mathrm{p}}=3.0(\mathrm{~s})$}

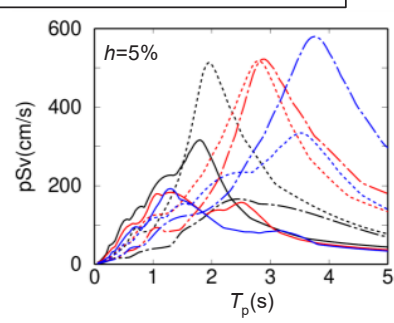

(b) $p S v(\mathrm{~h}=5 \%)$
Fig. 11 Floor response acceleration Spectra (norm. $\mathrm{H}=1.00)$

1 次固有周期 $T_{0}$ も図中に併記した。最大 $\mathrm{CoP}$ 変位および最大頭部速 度は，建物の PFD および PFV と同様に低層階よりも高層階で大き い。人体の忘答がピークとなる $T_{\mathrm{p}}$ は建物階数ごとに異なるものの, 建物の弾性時 1 次固有周期 $T_{0}$ より若干長い $T_{\mathrm{p}}$ で極大となり, その 


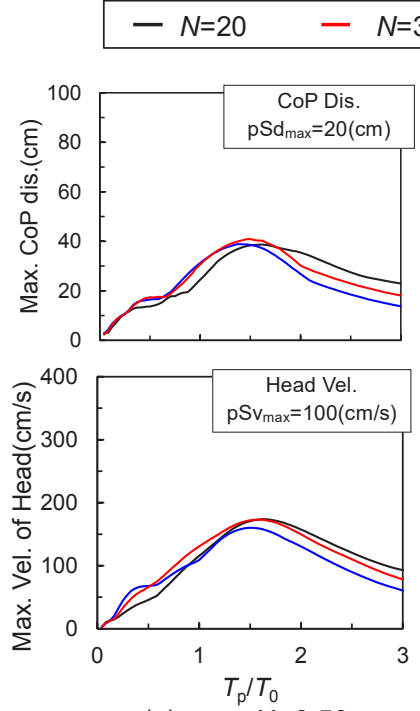

(a) norm. $\mathrm{H}=0.50$

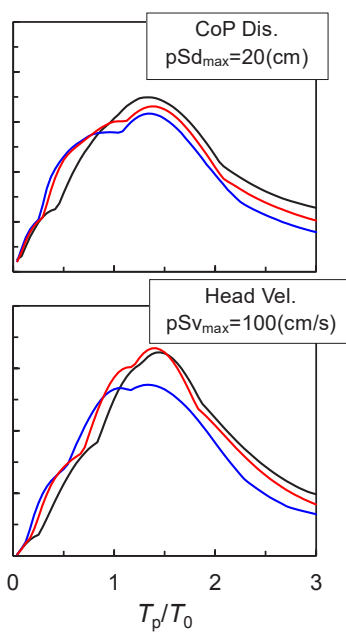

(b) norm. $\mathrm{H}=1.00$
Fig. 12 Relationship between $T_{p} / T_{0}$ and human responses

後単調減少する。その傾向は建物階数 $N$ によらず共通して見られ る。また, 既往波入力時の最大 $\mathrm{CoP}$ 変位および最大頭部速度は, Ricker 波による最大ピークに対しややばらつきが見られる。後述す るパルス性地震動の観測記録入力時との比較ではある程度の整合 性が見られることから，以降はRicker 波を利用した検討を進める。

$p S d_{\max }=20(\mathrm{~cm})$ および $p S v_{\max }=100(\mathrm{~cm} / \mathrm{s})$ における $T_{p}=1.0,2.0$, $3.0(\mathrm{~s})$, 建物階数 $N=20,30,40$ の床応答加速度の $p S d(h=5 \%)$ および $p S v(h=5 \%)$ を Fig. 11 に示す。建物の弾性時 1 次固有周期 $T_{0}$ より若干 長い $T_{\mathrm{p}}$ で極大となり, Fig. 10 の人体の応答がピークとなる $T_{\mathrm{p}}$ と対 応している。

そこで, Fig. 10 で得られた最大 $\mathrm{CoP}$ 変位および最大頭部速度を 統一的に扱うため, 建物への入力波の卓越周期 $T_{\mathrm{p}}$ を建物の 1 次固 有周期 $T_{0}$ で基準化する。 $T_{\mathrm{p}} / T_{0}$ と人体の最大応答の関係を Fig. 12 に 示す。 $T_{\mathrm{p}} / T_{0}$ の範囲は $0 \sim 3$ とし, $T_{\mathrm{p}}$ は最大で $7.2 \mathrm{~s}$ まで計算した。 $T_{\mathrm{p}} / T_{0}$ で整理することで最大 $\mathrm{CoP}$ 変位及び最大頭部速度の傾向は建 物階数 $N$ によらず概ね整合する。

次に, 振幅レベルによる変化を検討するため, $p S d_{\text {max }}$ を $10 \mathrm{~cm}$, $30 \mathrm{~cm}$ とした場合の $T_{\mathrm{p}} / T_{0}$ と最大 $\mathrm{CoP}$ 変位の関係および $p S v_{\max }$ を $50 \mathrm{~cm} / \mathrm{s}, 150 \mathrm{~cm} / \mathrm{s}$ とした場合の $T_{\mathrm{p}} / T_{0}$ と最大頭部速度の関係を Fig. 13 に示す。建物の基準化高さは 1.0 とした。振幅レベルが大きくな るほど, 建物固有周期の長周期化に伴いピークを生じさせる周期が やや長くなる。 $p S d_{\max }=30(\mathrm{~cm}), p S v_{\max }=150(\mathrm{~cm} / \mathrm{s})$ の $T_{\mathrm{p}} / T_{0}>1.0$ の範囲 でややばらつきが大きくなるものの, この範囲の応答レベルであれ ば, 建物階数 $N$ によらず人体の最大応答が整合し, 平均的な特性を 概初捉えることができる。

Fig. 12 および 13 で検討した結果をさらに統一的に扱うため, $T_{\mathrm{p}} / T_{0}$ を横軸に, $p S d_{\text {max }}, p S v_{\text {max }}$ を縦軸とし, 最大 $\mathrm{CoP}$ 変位および最 大頭部速度をコンタとして表示した結果を Fig. 14 に示す。ここで は，Fig. 12 および 13 に示した $N=20 ， 30 ４ 0$ の 3 ケースの結果 を平均している。なお, $p S d_{\text {max }}$ は $2 \mathrm{~cm}$ 間隔で $2 \sim 40 \mathrm{~cm}$ とし, $p S v_{\text {max }}$ は $10 \mathrm{~cm} / \mathrm{s}$ 間隔で $10 \sim 150 \mathrm{~cm} / \mathrm{s}$ とした入力波に対して計算を行った。 振幅レベルが大きくなるほど最大 $\mathrm{CoP}$ 変位および最大頭部速度は

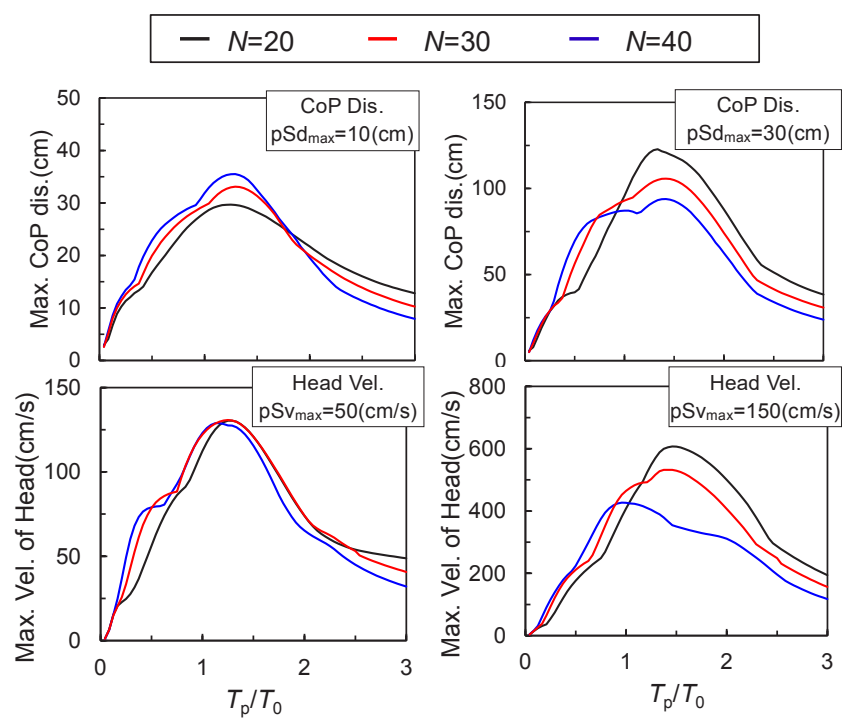

Fig. 13 Relationship between $T_{p} / T_{0}$ and human responses (norm. $\mathrm{H}=1.00$ )
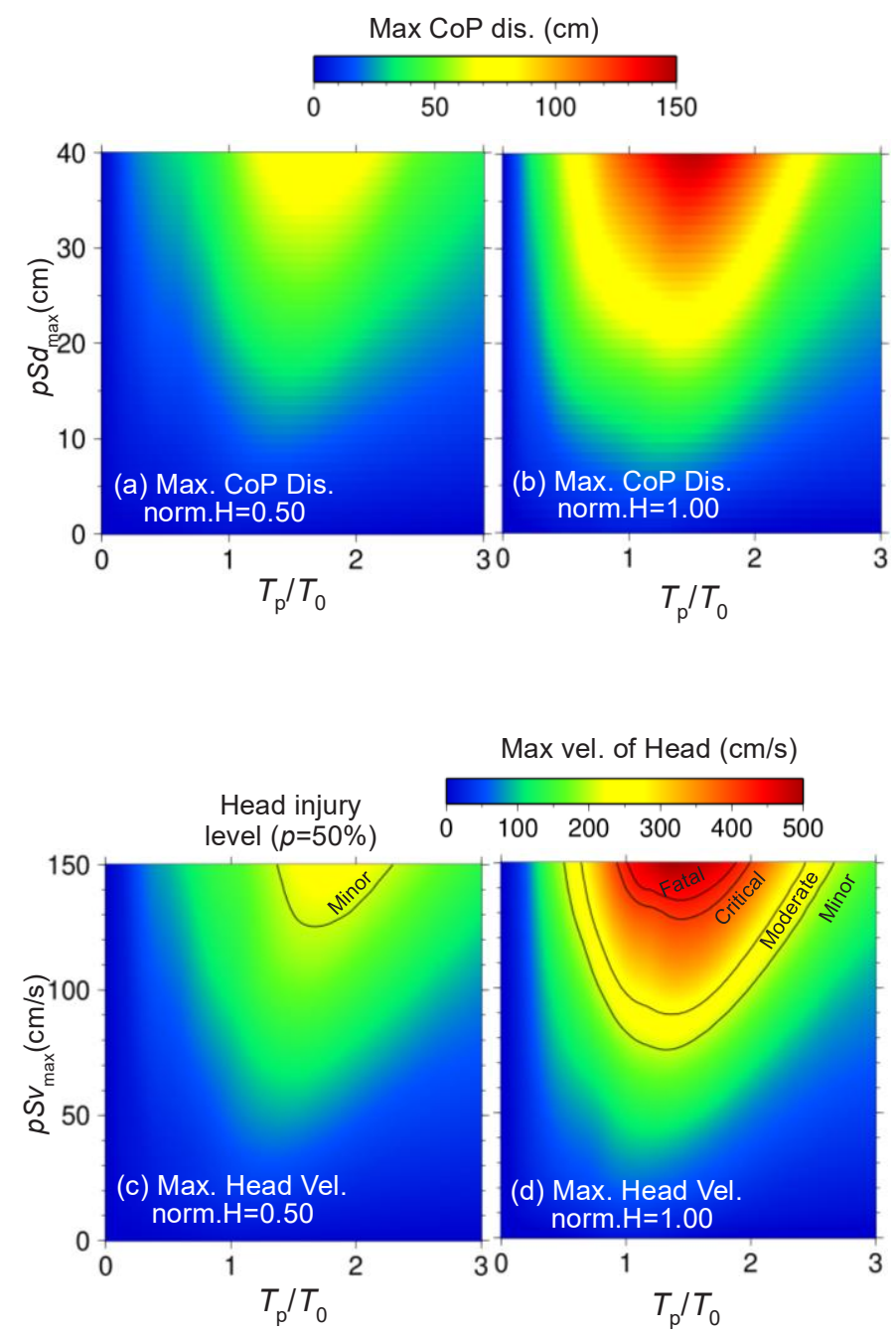

Fig. 14 Human response evaluation diagram in super-high-rise RC building excited by pulse-like ground motions 
大きくなり，ピークを生じる $T_{\mathrm{p}} / T_{0}$ が大きくなる傾向が見られる。 Fig. 14 (c), (d)には, Table 3 に示した頭部負傷度を最大頭部速度の 図中に併記した。パルス波の卓越周期が建物の非線形応答時の固有 周期と一致した場合, 建物頂部では $p S v_{\text {max }}=80(\mathrm{~cm} / \mathrm{s})$ 辺りから軽度の 頭部負傷(Minor) が発生し, $p S v_{\text {max }}=130(\mathrm{~cm} / \mathrm{s})$ 以上で致命的な負傷 (Critical)に至る可能性もある。

Fig. 14 を用いることで, 建物への入力地震動 $p S d_{\max }, p S v_{\max }$ 及び 卓越周期 $T_{\mathrm{p}}$, 超高層建物の 1 次固有周期 $T_{0}$ から, 超高層 $\mathrm{RC}$ 造建 物の人体の最大応答の傾向を把握することが可能となる。Fig. 14 を 「パルス性地震動に対する超高層建物内の人体応答評価ダイアグラ ム」(以降, 単に「人体応答評価ダイアグラム」) として提案し, これ 以降超高層建物内での人体応答を検討する際にこれを用いる。

\section{4. 実地震記録による人体応答と摇れの体感のアンケート調査結果} を用いた検証

本章では, 過去の実地震時に観測されたパルス性地震動を用い て, 前章で示した Ricker 波入力時の超高層集合住宅における人体応

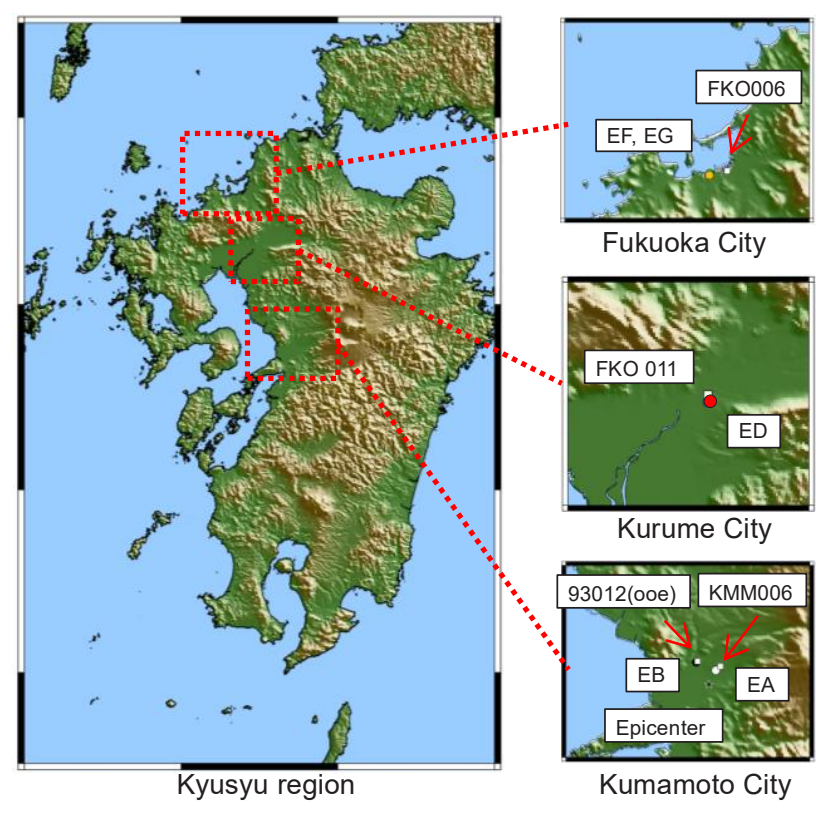

Fig. 15 Location of buildings in this study and strong motion observation in Kyusyu region
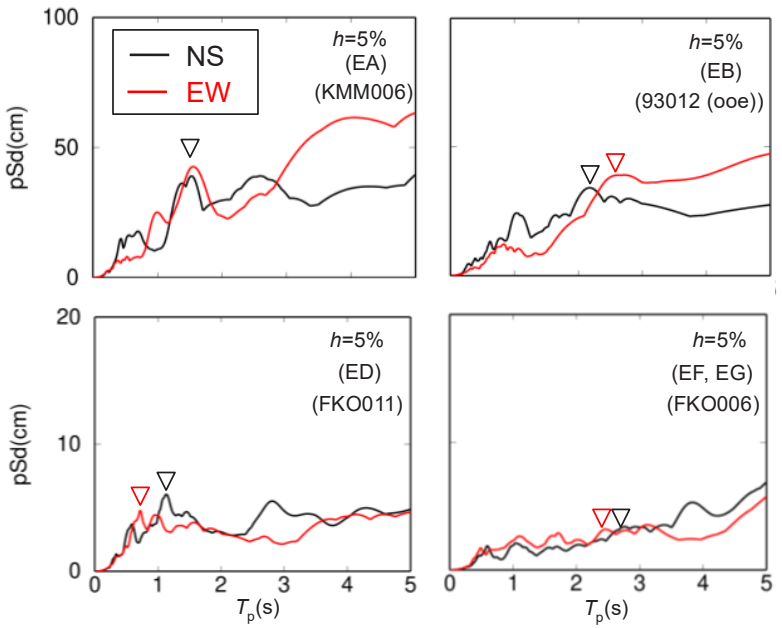

Fig. 17 Pseudo-displacement response spectra at each site
答の評価結果を検証する。まず, 2016 年熊本地震本震や 2018 年大 阪府北部の地震時等の地表での強震記録を超高層建物モデルに入力 し, 得られた各階の床応答を人体モデルに入力して人体の応答を求 める。そして，上記の地震時における超高層集合住宅居住者を対象 に実施した摇れの体感に関するアンケート調查と人体応答の評価結 果を比較し, 人体応答の妥当性を検討する。さらに, Fig. 14 に示し たパルス性地震動に対する超高層建物の人体応答評価ダイアグラム で評価される結果と人体モデルにより求めた人体応答を比較し, 人 体応答評価ダイアグラムの妥当性を検証する。

\subsection{6 年熊本地震の強震記録を用いた検証}

2016 年熊本地震本震時には, 地表地震断層が広範囲で確認され, 益城町と西原村で大振幅のパルス性地震動が観測された。その強震 記録を用いて，九州に建つ超高層集合住宅 5 棟の地震応答解析を行 う。使用する建物モデルは前章と同様にせん断型多質点系モデルで あり，減衰定数等の条件も同じ設定とした。

\begin{tabular}{|c|c|c|c|c|c|c|c|}
\hline $\begin{array}{c}\text { Building } \\
\text { name }\end{array}$ & Location & Structure & $\begin{array}{c}\text { Number of } \\
\text { stories }\end{array}$ & $\begin{array}{c}\text { Year of } \\
\text { completion }\end{array}$ & $\begin{array}{r}\text { Corres } \\
\text { flo }\end{array}$ & $\begin{array}{l}\text { onding } \\
\text { ors }\end{array}$ & $\begin{array}{l}\text { Number of } \\
\text { respondents }\end{array}$ \\
\hline \multirow{3}{*}{ EA } & \multirow{3}{*}{$\begin{array}{l}\text { Kumamoto City, } \\
\text { Kumamoto }\end{array}$} & \multirow{3}{*}{ SRC } & \multirow{3}{*}{20} & \multirow{3}{*}{2003} & Upper & \begin{tabular}{|l|l}
15 &
\end{tabular} & 12 \\
\hline & & & & & Middle & $8 \sim 14$ & 17 \\
\hline & & & & & Lower & $1 \sim 7$ & 27 \\
\hline \multirow{3}{*}{$E B$} & \multirow{3}{*}{$\begin{array}{l}\text { Kumamoto City, } \\
\text { Kumamoto }\end{array}$} & \multirow{3}{*}{ RC } & \multirow{3}{*}{25} & \multirow{3}{*}{2006} & Upper & 18 25 & 11 \\
\hline & & & & & Middle & \begin{tabular}{|l|l}
$10 \sim 17$ \\
\end{tabular} & 25 \\
\hline & & & & & Lower & $2 \sim 9$ & 24 \\
\hline \multirow{3}{*}{ ED } & \multirow{3}{*}{$\begin{array}{l}\text { Kurume City, } \\
\text { Fukuoka }\end{array}$} & \multirow{3}{*}{$\mathrm{RC}$} & \multirow{3}{*}{19} & \multirow{3}{*}{2012} & Upper & 14 19 & 21 \\
\hline & & & & & Middle & $8 \sim 13$ & 22 \\
\hline & & & & & Lower & $2 \sim 7$ & 20 \\
\hline \multirow{3}{*}{ EF } & \multirow{3}{*}{$\begin{array}{l}\text { Fukuoka City, } \\
\text { Fukuoka }\end{array}$} & \multirow{3}{*}{ RC } & \multirow{3}{*}{20} & \multirow{3}{*}{1995} & Upper & \begin{tabular}{|l|l}
$15 \sim 19$ \\
\end{tabular} & 12 \\
\hline & & & & & Middle & $8 \sim 14$ & 15 \\
\hline & & & & & Lower & $1 \sim 7$ & 16 \\
\hline \multirow{3}{*}{ EG } & \multirow{3}{*}{$\begin{array}{l}\text { Fukuoka City, } \\
\text { Fukuoka }\end{array}$} & \multirow{3}{*}{$\mathrm{RC}$} & \multirow{3}{*}{27} & \multirow{3}{*}{2004} & Upper & \begin{tabular}{|l|l}
$19 \sim 27$ \\
\end{tabular} & 17 \\
\hline & & & & & Middle & \begin{tabular}{|l|l}
$10 \sim 18$ \\
\end{tabular} & 36 \\
\hline & & & & & Lower & $2 \sim 9$ & 33 \\
\hline
\end{tabular}

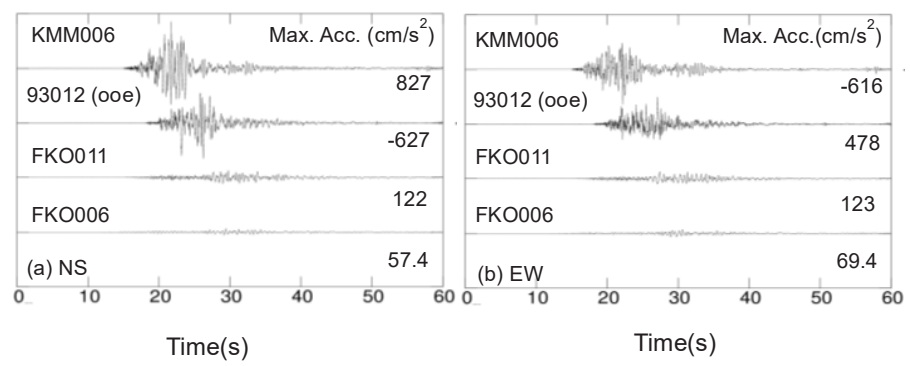

Fig. 16 Acceleration time histories at each site
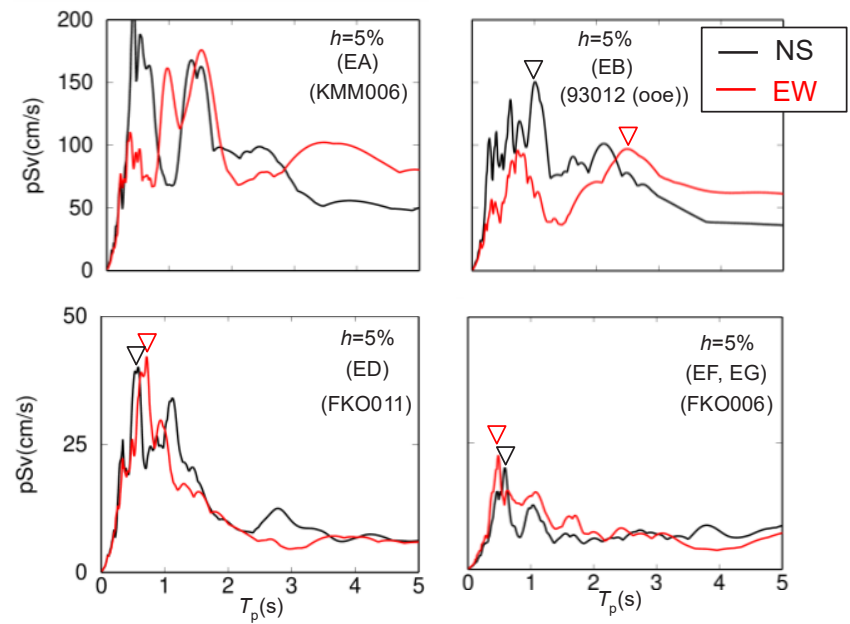

Fig. 18 Pseudo-velocity response spectra at each site 


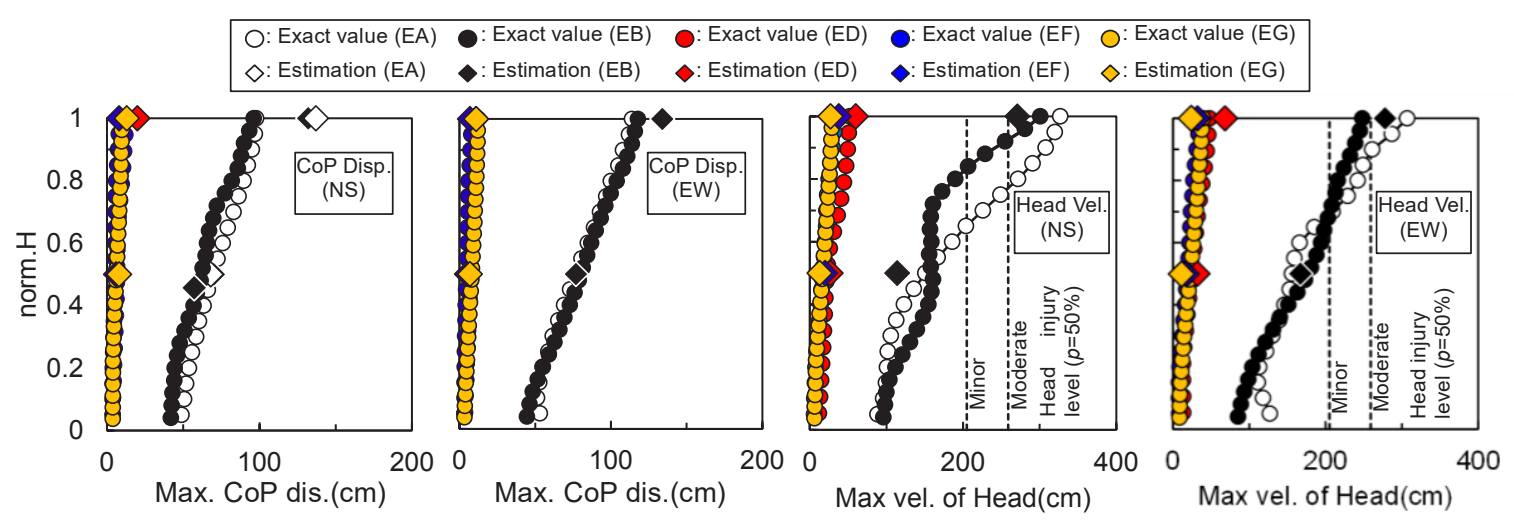

Fig. 19 Height-wise distribution of human responses

Table 5 Answer items about action difficulty and corresponding scores ${ }^{26)}$

\begin{tabular}{cc}
\hline Answer items & $\begin{array}{c}\text { Action } \\
\text { difficulty }\end{array}$ \\
\hline Could not act on my own will because of being swayed by shaking & 4 \\
\hline Could not hold my standing posture & 3 \\
\hline There was a slight hindrance to walking and moving & 2 \\
\hline Felt a clear shaking, but there was no hindrance to action & 1 \\
\hline Felt a slight shaking, but there was no hindrance to action & 0
\end{tabular}

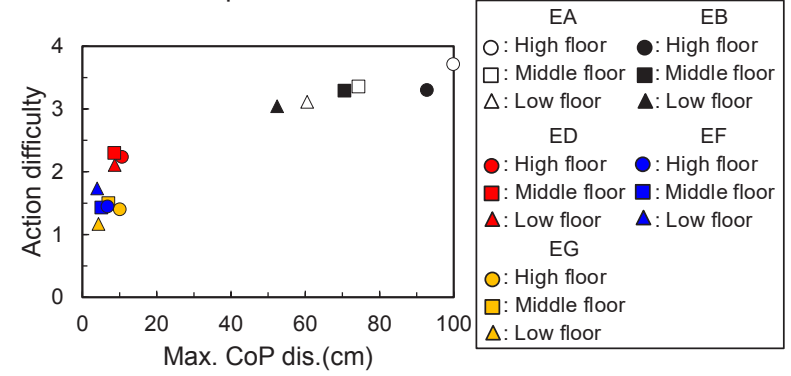

Fig. 20 Relationship between maximum human response and action difficulty
検討対象建物の建設位置と強震記録の観測点位置を Fig. 15 に示 す。また, 各建物の概要を Table 4 に示す。各建物の地震応答解析に 用いる入力波は, 各建物位置から最も近くに位置する K-NET また は地方公共団体震度計の強震観測点の記録である。建物 EA, EB お よび ED には KMM006，93012(大江)および FKO011 の記録を入力 し, 建物 EF と EG には双方とも FKO006 の記録を入力する。本震時 に観測されたそれぞれの観測点位置の NS, EW 方向の時刻歴加速度 波形を Fig.16 に示し, $p S d(h=5 \%)$ および $p S v(h=5 \%)$ を Fig. 17 および 18 に示寸。同図には, 人体応答の推定で用いる各地震波の $T_{\mathrm{p}}$ を併記 している。なお， $p S d(h=5 \%)$ は $T_{\mathrm{p}}$ とともに漸増する傾向にあるが， ここでは超高層建物の固有周期に対応させるため, $\mathrm{pSd}_{\text {max }}$ の評価に 用いる $T_{\mathrm{p}}$ をとる範囲を $0 \sim 3 \mathrm{~s}$ とした。建物 $\mathrm{EA} の p S d(h=5 \%)$ の $\mathrm{EW}$ 方向, $p S v(h=5 \%)$ のS ・ EW 方向のように $p S d_{\text {max }}$ が $40 \mathrm{~cm}, p S v_{\text {max }}$ が $150 \mathrm{~cm} / \mathrm{s}$ を超える場合は, Fig. 14 に示した人体応答評価ダイアグラ ムの適用範囲外として除外した。次節以降も同様に扱った。

各建物における人体の最大応答の高さ分布 Fig. 19 に示す。いずれ のケースも最大 $\mathrm{CoP}$ 変位及び最大頭部速度は下層階から上層階に向 かって増大している。震源に近い建物 EA, EB では最上階付近の人 間は摇れに大きく翻弄され，立位姿勢を保持するために確保できる 床面積が小さい場合には踏み外しや転倒・転落の危険性が高かった と予想される。最大頭部速度も Moderate に対応している。

日野浦ら ${ }^{26)}$, 渡辺ら ${ }^{28)}$ は, 20 階建てもしくは軒高 $60 \mathrm{~m}$ 以上の九 州に建つ超高層集合住宅の居住者に対し, 2016 年熊本地震本震時の 建物内における室内被害や摇れの体感に関するアンケート調查を行 った。本研究では, そのアンケート調查結果を用いて人体応答の評 価結果の妥当性を検証する。本研究で検討対象とする建物は, 文献 27), 28)に示されている建物のうち, 制震および免震構造を除く 5 棟 とする。

摇れの最中の行動難度に関するアンケート内容を Table 5 に示す。
アンケートは選択式で,「あなたの感じた地震の摇れの大きさは, ど のくらいでしたか。」との質問に,「摇れに翻弄され, 自分の意志で 何も行動できなかった」,「立っていることができなかった」,「歩い たり動いたり寸ることに, やや支障があった」,「はっきりした摇れ を感じたが，行動には支障がなかった」および「わずかに摇れを感 じたが，行動には支障がなかった」のいずれかから回答を選択する 形式である。各回答項目に対し, 4 0 の数值を割り当てて行動難度 を数值化し, 各建物, 高さレベル(高層, 中層, 低層)ごとに平均值を 求めた。

ここで, アンケート調査は水平・鉛直三方向に摇れる実地震を経 験した超高層集合住宅の居住者に対して実施したものである。一方， 本研究で用いる人体モデルは水平一方向入力に対する人間の前後方 向のみの応答を求めるものである。ここでは水平二方向入力の影響 を考慮するため, 検討対象建物における熊本地震時の観測記録に対 して $15^{\circ}$ 毎に各方角の床応答加速度波形を求めて人体モデルに入力 し, 各方角の最大 $\mathrm{CoP}$ 変位の平均值を用いて検討を行う。

最大 $\mathrm{CoP}$ 変位とアンケート調査による行動難度の関係を Fig. 20 に示す。アンケート調查において建物 EA,EB で行動難度が 3 (立っ ていることができない）４（摇れに翻弄され，自分の意志で何も行 動ができない）程度であり, 最大 $\mathrm{CoP}$ 変位は下層階から上層階に向 かって約 $50 \mathrm{~cm}$ 以上で推移している。熊本地震時の観測記録に対寸 る人体の最大応答の高さ分布はアンケート調查の行動難度からその 妥当性が示される。

Fig. 14 に示した人体応答評価ダイアグラムの妥当性を検証するた め, 同ダイアグラムによる人体応答の評価結果を Fig. 19 に併記し た。これ以降，人体応答評価ダイアグラムによる推定結果を「推定 值」と呼び, 床応答を人体モデルに入力して求めた結果を「精解值」 と呼ぶこととする。人体の最大応答の推定值は, 精解值と若干差異 が見られる部分はあるものの, 両者は概ね対応している。このこと 


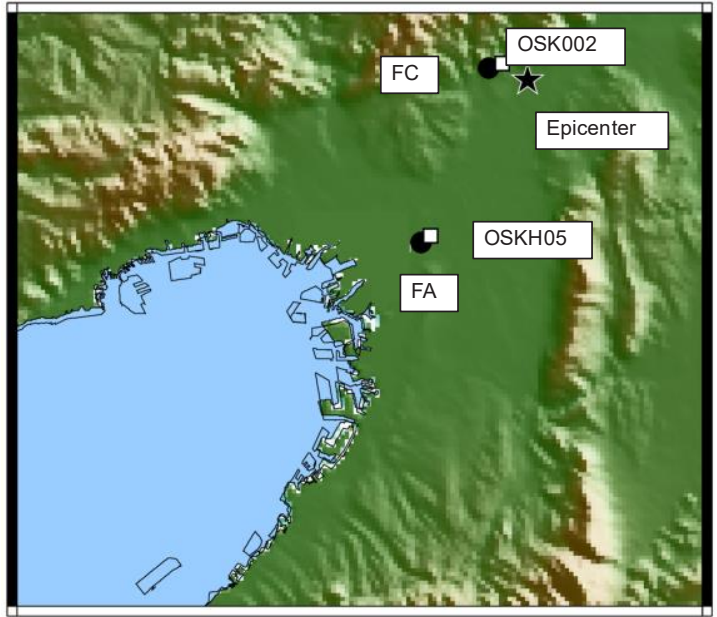

Fig. 21 Location of target buildings $(0)$ and strong motion observation sites $(\square)$ in Osaka
Table 6 Target buildings in Kansai region

\begin{tabular}{|c|c|c|c|c|c|c|c|}
\hline $\begin{array}{l}\text { Building } \\
\text { name }\end{array}$ & Location & Structure & $\begin{array}{c}\text { Number of } \\
\text { stories }\end{array}$ & $\begin{array}{c}\text { Year of } \\
\text { completion }\end{array}$ & \multicolumn{2}{|c|}{$\begin{array}{c}\text { Corresponding } \\
\text { floors }\end{array}$} & $\begin{array}{c}\text { Number of } \\
\text { respondents }\end{array}$ \\
\hline \multirow{3}{*}{ FA } & \multirow{3}{*}{$\begin{array}{l}\text { Osaka City, } \\
\text { Osaka }\end{array}$} & \multirow{3}{*}{$\mathrm{RC}$} & \multirow{3}{*}{28} & \multirow{3}{*}{2005} & Upper & \begin{tabular}{|l|}
$19 \sim 28$ \\
\end{tabular} & 40 \\
\hline & & & & & Middle & \begin{tabular}{|l|}
$10 \sim 18$ \\
\end{tabular} & 37 \\
\hline & & & & & Lower & $6 \sim 9$ & 15 \\
\hline \multirow{3}{*}{ FC } & \multirow{3}{*}{$\begin{array}{c}\text { Takatsuki City, } \\
\text { Osaka }\end{array}$} & \multirow{3}{*}{$\mathrm{RC}$} & \multirow{3}{*}{20} & \multirow{3}{*}{1994} & Upper & 15 20 & 8 \\
\hline & & & & & Middle & 7 14 & 11 \\
\hline & & & & & Lower & $2 \sim 6$ & 9 \\
\hline
\end{tabular}

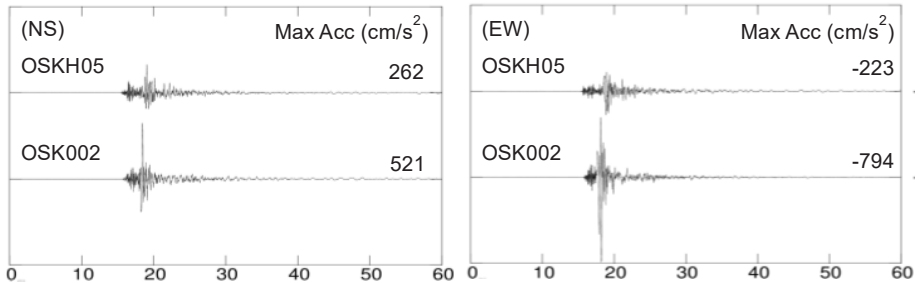

Fig. 22 Acceleration time histories at each site

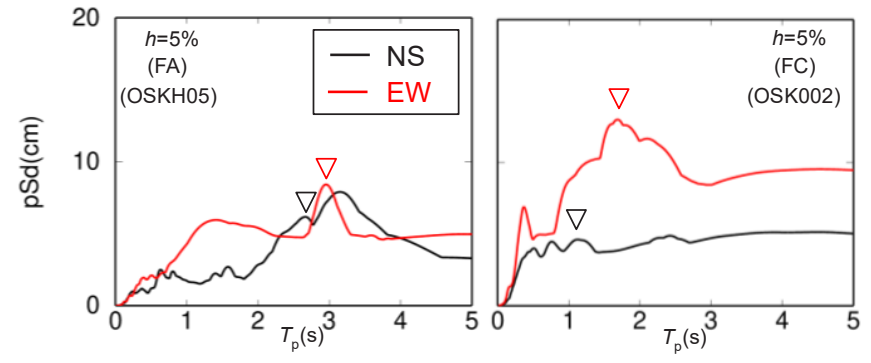

Fig. 23 Pseudo-displacement response spectra at each site

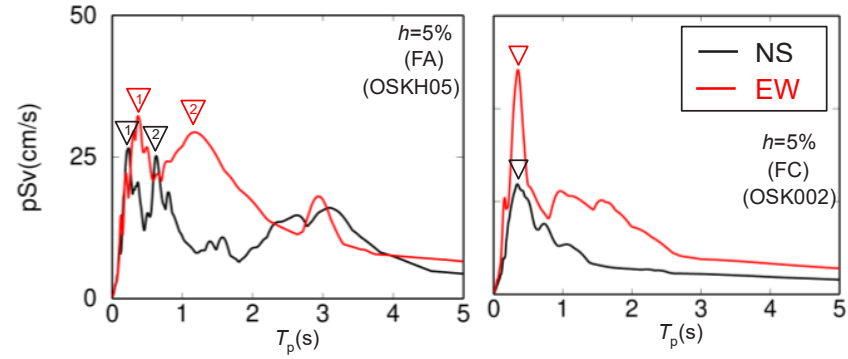

Fig. 24 Pseudo-velocity response spectra at each site

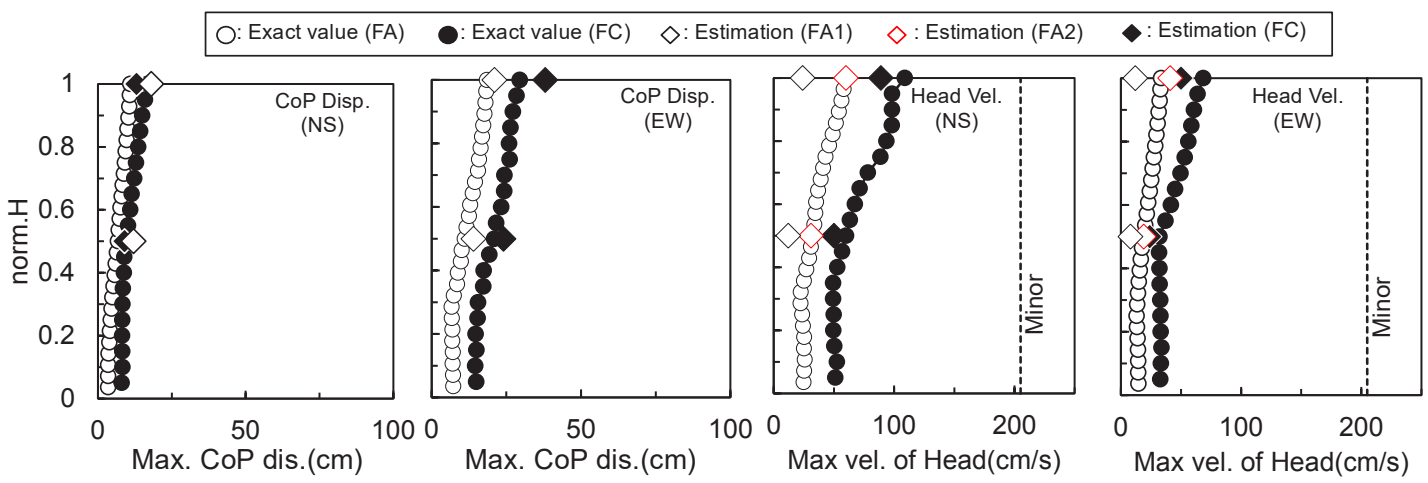

Fig. 25 Height-wise distribution of human responses

から，人体応答評価ダイアグラムが妥当であることが分かる。

\subsection{8 年大阪府北部の地震の強震記録を用いた検証}

次に, 2018 年大阪府北部の地震の観測記録を用いて人体応答評価 ダイアグラムの妥当性を検討する。

2018 年 6 月 18 日に発生した大阪府北部を震源とする地震では, 大阪府北摂地域において, 震度 6 弱を伴う強い摇れとなり, 周期 1 秒以下で卓越する地震動が多く観測された。

検討対象建物の建設位置および強震記録の観測点位置を Fig.21に 示寸。対象建物 2 棟をそれぞれ建物 FA, 建物 FC とし, これらの建 物概要を Table 6 に示す。

検討対象建物の地震応答解析を行う。各建物の地震応答解析に用 いる入力波は，各建物位置から最も近くに位置する K-NET または KiK-net の強震観測点の記録である。建物 FA および FC には OSKH05 および OSK002 の記録を入力する。使用する建物モデルは前節と同
様にせん断型多質点系モデルとする。本震時に観測されたそれぞれ の観測点位置の NS, EW 方向の時刻歴加速度波形を Fig. 22 に示す。 また, $p S d(h=5 \%), p S v(h=5 \%)$ を Fig.23，Fig.24に示す。同図には，人 体応答の推定で用いる各地震波の $T_{\mathrm{p}}$ を併記している。建物 FA の

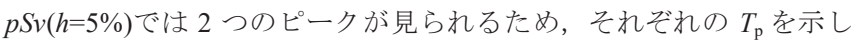
た。

建物の地震応答解析により得られた各階の床応答を人体モデルに 入力し, 人体の応答を求めた。各建物における人体応答の高さ分布 を Fig. 25 に示す。いずれのケースも最大 $\mathrm{CoP}$ 変位及び最大頭部速 度は下層階から上層階に向かって増大寸る。建物 FA より震源に近 い建物 FC の方が，最大 $\mathrm{CoP}$ 変位及び最大頭部速度は大きい。建物 $\mathrm{FA}$, 建物 FC の最大 $\mathrm{CoP}$ 変位は熊本地震と比べ小さかった。最大頭 部速度も Minor にも満たず, 頭部負傷の可能性は低かったと言える。 前節と同様に, 人体応答の評価結果の妥当性を検討寸るため, 検 


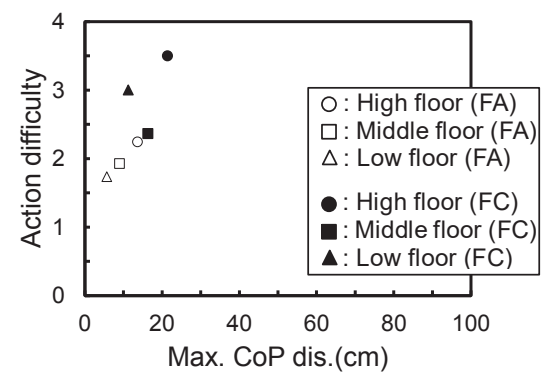

Fig. 26 Relationship between max. CoP dis. of human and action difficulty

Max. Acc.

\begin{tabular}{|c|c|c|c|}
\hline JR-Takatori & $\left(\mathrm{cm} / \mathrm{s}^{2}\right)$ & JR-Takatori & $\left(\mathrm{cm} / \mathrm{s}^{2}\right)$ \\
\hline Kawaguchi-cho & 10 & Kawaguchi-cho & 132 \\
\hline K-NET Mukawa & 111 & K-NET Mukawa & \\
\hline (a-1) NS direction & & (a-2) EW direction & \\
\hline 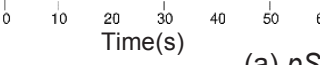 & 50 & $\begin{array}{lllll}10 & 20 & 30 & 40 & 50 \\
& \text { Time(s) }\end{array}$ & 60 \\
\hline
\end{tabular}

(a) $p S d_{\max }=20(\mathrm{~cm})$

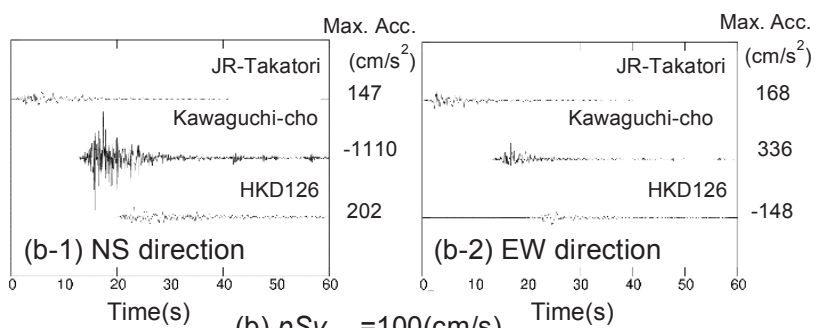

(b) $p S v_{\max }=100(\mathrm{~cm} / \mathrm{s}) \quad$ Time $(\mathrm{s})$

Fig. 27 Acceleration time histories at each site

討対象建物の居住者に対して実施した摇れの体感に関するアンケー 卜調査 ${ }^{29}$ の結果と人体応答を比較する。摇れの最中の行動難度に関 するアンケート内容は前節で示した Table 5 と同様である。

最大 $\mathrm{CoP}$ 変位とアンケート調査による行動難度の関係を Fig. 26 に 示す。アンケート調查においても大半の建物での行動難度は 3 未満 であったが，最も震源に近い建物 FC の下層階・上層階では行動難 度が 3 以上で最大 $\mathrm{CoP}$ 変位は約 $20 \mathrm{~cm}$ 程度であり, Fig. 20 に示した 行動難度よりも大きい傾向にあった。建物 FC の入力波に使用した OSK002の $p S v(h=5 \%)$ は $0.5 \mathrm{~s}$ 付近で卓越し最大加速度は $800 \mathrm{~cm} / \mathrm{s}^{2}$ 程 度と短周期成分が卓越しており, それにより行動難度が大きめにな った可能性もある。一方, 最大 $\mathrm{CoP}$ 変位が大きい場合に行動難度が 大きくなる傾向は共通であり大阪府北部の地震時の観測記録に対す る人体の最大応答とアンケート調査の行動難度には, 対応関係が確 認される。

人体応答評価ダイアグラムの妥当性を検証するため, 同ダイアグ ラムから求めた基準化高さ $0.5,1.0$ における人体の最大応答推定值 を Fig. 25 に併記した。人体応答評価ダイアグラムによる人体の最大 応答推定値は, 精解值の最大応答の傾向と概ね整合する。ただし, 建物 FA の NS 方向の $p S v(h=5 \%)$ では短周期側と長周期側に 2 つのピ 一クが見られ (Fig. 24), 短周期側の $T_{\mathrm{p}}$ を用いて評価した最大頭部 速度は精解值に比心過小評価となる。一方， $0.8 \sim 1.5 \mathrm{~s}$ のやや長周期 側の $T_{\mathrm{p}}$ を用いた場合には, 人体応答の推定值が精解值と良好に対応 する。

応答スペクトルのピークが複数見られる地震波の評価については
Table 7 Earthquake records used in this study

\begin{tabular}{|c|c|c|c|c|c|}
\hline \multirow{2}{*}{ Earthquake } & \multirow{2}{*}{ Point } & \multirow{2}{*}{ Direction } & \multicolumn{3}{|c|}{ Symbol } \\
\hline & & & $N=20$ & $N=30$ & $N=40$ \\
\hline \multirow{2}{*}{$\begin{array}{l}\text { The } 1995 \text { Hyogo-ken } \\
\text { Nanbu Earthquake }\end{array}$} & \multirow{2}{*}{ JR-Takatori } & NS & & 0 & \\
\hline & & EW & 0 & 0 & 0 \\
\hline \multirow{2}{*}{$\begin{array}{l}\text { The Niigataken Chuetsu-oki } \\
\text { Earthquake in } 2007\end{array}$} & \multirow{2}{*}{$\begin{array}{l}\text { Kawaguchi- } \\
\text { cho }\end{array}$} & NS & & 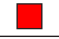 & \\
\hline & & EW & $\square$ & $\square$ & $\square$ \\
\hline \multirow{2}{*}{$\begin{array}{l}\text { The Hokkaido Eastern Iburi } \\
\text { Earthquake in } 2018\end{array}$} & \multirow{2}{*}{ HKD126 } & NS & $\Delta$ & $\Delta$ & $\Delta$ \\
\hline & & EW & $\triangle$ & $\triangle$ & $\triangle$ \\
\hline
\end{tabular}

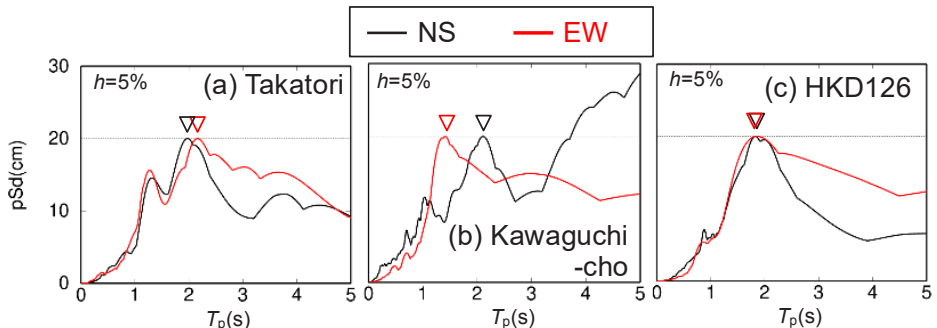

Fig. 28 Pseudo-displacement response spectra at each site

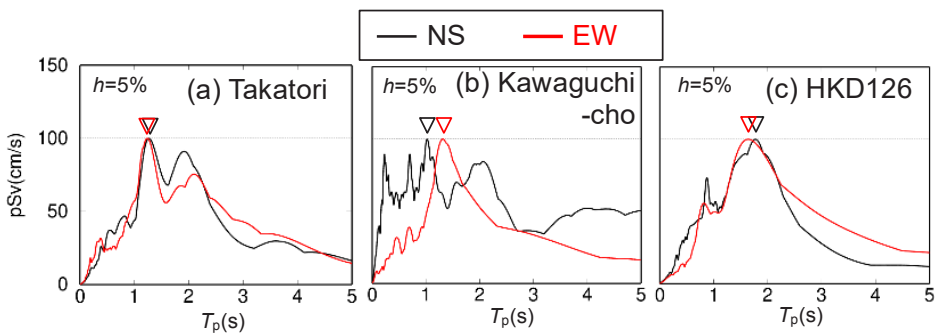

Fig. 29 Pseudo-velocity response spectra at each site
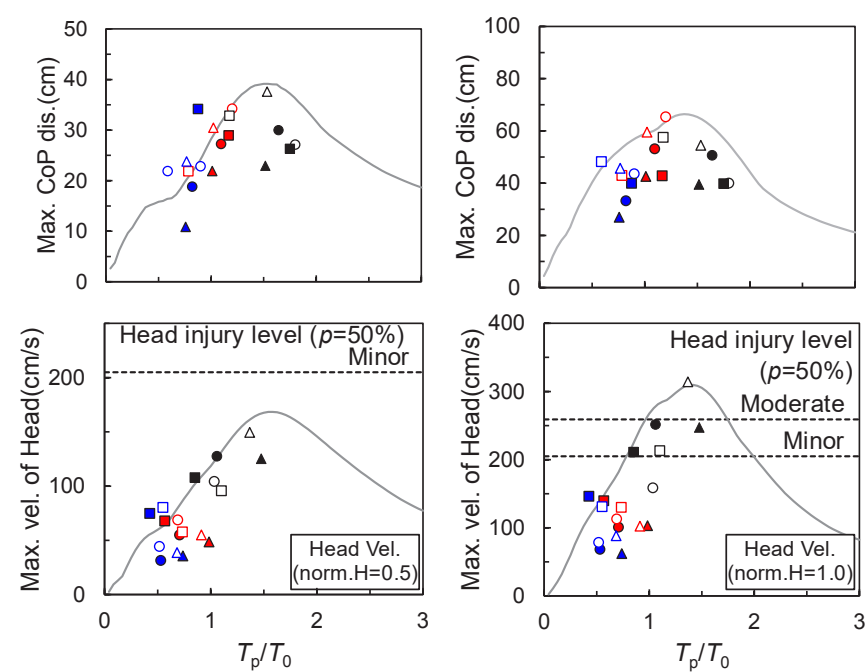

Fig. 30 Comparison between estimation by Ricker wavelet and analysis by observed waves

今後の課題となるが，人体応答評価ダイアグラムによる人体の最大 応答推定值により実地震時の人間応答をある程度評価できるものと 考えられる。

\section{3 その他のパルス性地震動}

さらに, 過去に発生した地震時に観測されたパルス性地震動を利 用して, 人体応答評価ダイアグラムの妥当性を検討する。

対象とする钼測地震波の概要を Table 7 に示す。 $p S d_{\text {max }}$ を $20 \mathrm{~cm}$ に 基準化したもの及び $p S v_{\text {max }}$ を $100 \mathrm{~cm} / \mathrm{s}$ に基準化した $\mathrm{NS}, \mathrm{EW}$ 方向の 
時刻歴加速度波形を Fig. 27 に示し, $p S d(h=5 \%), p S v(h=5 \%)$ を Fig. 28 , Fig. 29 に示す。

これらの地震波を用いた建物の地震応答解析を行い, その各階の 床応答を人体モデルに入力して得られた人体の最大応答を Fig. 30 に示す。建物モデルの建物階数 $N$ は $20,30,40$ の 3 パターンとし た。なお, 同図のプロットのシンボルは Table 7 の “シンボル” 欄に 示したものと対応している。また, 前章で得られた人体応答評価ダ イアグラムによる推定值も併記した。人体応答の推定値は精解值と 比べて過大評価となるものもあるが，推定值を大きく超えるものは ない。

以上から, 人体応答評価ダイアグラムによる人体の最大応答の推 定值は, 地震時における人体応答の上限值を評価可能であることが 示された。

\section{5. まとめ}

本研究では, 超高層集合住宅の居住者を対象とし, パルス性地震 動入力時の多質点せん断モデル及び台車型二重倒立振子による人体 の地震応答解析モデルを用い, 超高層集合住宅における負傷予測に 向けた人体応答の評価を検討した。パルス性地震動として Ricker 波 を利用し, パルス性地震動に対する超高層建物内の人体応答評価ダ イアグラムを提案し, 過去に得られた実地震時のパルス性地震動を 用いてその妥当性を検証した。得られた知見を以下に示す。

1) Ricker 波入力時の超高層建物内での人体の最大 $\mathrm{CoP}$ 変位およ び最大頭部速度は，低層階から高層階に向けて大きくなった。

2) 超高層集合住宅への入力波となるパルス波の擬似変位応答ス ペクトルの最大值 $p S d_{\max }$, 擬似速度応答スペクトルの最大值 $p S v_{\max }$ およびそれらの卓越周期と建物の 1 次固有周期の比 $T_{\mathrm{p}} / T_{0}$ を用いた，建物内における人体の最大応答の評価法 (パルス性 地震動に対する超高層建物内の人体応答評価ダイアグラム) を 構築した。

3) 建物への入力となるパルス波の卓越周期が建物の非線形応答 時の固有周期と一致した場合, 建物頂部では $p S v_{\text {max }}=80(\mathrm{~cm} / \mathrm{s})$ 辺 りから軽度の負傷が発生し, $p S v_{\text {max }}=130(\mathrm{~cm} / \mathrm{s})$ 以上で致命的な負 傷に至る可能性がある。

4) 人体モデルにより算定された床反力中心 $(\mathrm{CoP})$ の最大変位が大 きくなるほど, 実地震時の超高層集合住宅居住者を対象とした 地震時の摇れの体感に関するアンケート調査による行動難度 が大きくなる傾向にあった。

5) 人体モデルにより求めた人体の最大 $\mathrm{CoP}$ 変位および最大頭部 速度と, 人体応答評価ダイアグラムを用いて評価したそれらを 比較し，両者が概㸚対応することを確認した。

\section{謝辞}

本検討では防災科学技術研究所: 強震観測網 (K-NET·KiK-net), 気象庁，鉄道総合技術研究所の各強震記録を利用させていただきま した。アンケートに回答していただいた超高層集合住宅の居住者の 皆様には大変貴重なご意見をいただきました。本論文の作成には GMT を利用させていただきました。また, 本研究は令和元年度科学 研究費補助金基盤研究(B) No. 19H02399（代表：肥田剛典），令和 2 年度科学研究費補助金基盤研究(C) No. 20K04668（代表：永野正行）
の助成を受けて遂行しました。ここに記して感謝の意を表します。

参考文献

1) Narushima, K., Nagano, M., Suzuki, K., Uebayashi, H., Tanuma, T. and Oda, S.: Estimation and simplified evaluation of peak inter-story drift angle during massive earthquake for RC super high-rise residential buildings in Japan, Journal of Japan Association for Earthquake Engineering, Vol. 17, No. 5, pp. 96-108, 2017.11 (in Japanese)

成島慶，永野正行，鈴木賢人，上林宏敏，田沼毅彦，小田聡 : 国内に建つ 超高層集合住宅の大地震時における最大平均層間変形角の推定と簡易評 価，日本地震工学会論文集，第 17 巻，第 5 号,pp. 96-108, 2017.11

2) Okada, S. and Tamura, A.: Casualty Reduction Measures based on Microanaly sis of Human Behaviors in Seismic Damage Buildings, Report of Tono Research Institute of Earthquake Science, No. 15, pp. 88-120, 2005.4 (in Japanese) 岡田成幸，田村篤：被震下建物内で発生する人的被害の軽減化対策規範 構築を目的とした被災事例ミクロ解析, 東濃地震科学研究所報告, No. 15, pp. 88-120, 2005. 4

3) Okada, S., Nachi, N., Tamori, S., Watanabe, C., and Sawada, M.: An Intensive Hearing Investigation to Households Damaged in the 2004 Niigata-Ken Chuetsu Earthquake, Report of Tono Research Institute of Earthquake Science, No. 18, pp. 65-157, 2006. 3 (in Japanese)

岡田成幸, 名知典之, 田守伸一郎, 渡辺千明, 澤田雅浩: 2004 年新潟県中 越地震における室内人的被害調査, 東濃地震科学研究所報告, No. $18, \mathrm{pp}$. 65-157, 2006. 3

4) Tanaka, A., Nakamura, I., Udagawa, S., Nakamori, H., Sekiya, N., Magoshi, N., and Hiroi O.: Some Problems of the Information Dissemination and Behaviors of the Inhabitants at the Miyagi-ken Oki Earthquake, 2003.5, The Research Bulletin of the Institute of Socio-Information and Communication Studies, The University of Tokyo, No. 21, pp. 1-106, 2004. 3 (in Japanese)

田中淳, 中村功, 宇田川真之, 中森広道, 関谷直也, 馬越直子, 廣井脩: 2003 年 5 月 宮城県沖の地震等における住民の行動に関する調査, 東京 大学社会情報研究所調查研究紀要, No. 21, pp. 1-106, 2004. 3

5) Tokyo Fire Department: Result of Research on the Actual Situation about Indoor Damage due to the 2016 Kumamoto Earthquake, https://www.tfd.metro.tokyo.lg. jp/hp-bousaika/report/2018/03/index.html, (accessed 2020.1.27), (in Japanese) 東京消防庁: 平成 28 年 (2016 年) 熊本地震に伴う室内被害の実態調査 結果, https://www.tfd.metro.tokyo.lg.jp/hp-bousaika/report/2018/03/index.html (参照 2020.1.27)

6) Shizuoka Prefecture: Outline of Damage due to 2009.8.11 Suruga Bay Earthquake and Disaster Prevention Measures, 2011. 3, http://www.pref.shizuoka.jp/bousai/e-

quakes/shiraberu/higai/surugawanjishin/index.html,(accessed 2020.1.27), (in Japanese)

静岡県: 平成 21 年 8 月 11 日の駿河湾を震源とする地震被害及び防災対 応の概要, 2011.3, http://www.pref.shizuoka.jp/bousai/e-quakes/shiraberu/higai /surugawanjishin/index.html, (参照 2020. 1. 27)

7) Suzuki, K., Kawabe, H., Yamada, M. and Hayashi, Y.: Design Response Spectra for Pulse-Like Ground Motion, Journal of Structural and Construction Engineering (Transactions of AIJ), Vol. 75, No. 647, pp. 49-56, 2010. 1 (in Japanese)

鈴木恭平, 川辺秀憲, 山田真澄, 林康裕 : 断層近傍のパルス性地震動特性 を考慮した設計用応答スペクトル, 日本建築学会構造系論文集, 第 75 巻, 第 647 号, pp. 49-56, 2010.1

8) Kamei, I., Satou, K. and Hayashi, Y.: Evaluation Based on Model Analysis of Response Drift in MDOF Systems Subjected to Pulse Wave Ground Motions, Journal of Structural and Construction Engineering (Transactions of AIJ), Vol. 75 , No. 649, pp. 567-575, 2013. 3 (in Japanese)

亀井功, 佐藤浩太郎, 林康裕：モーダル解析によるパルス性地震動に対 する多自由度系の層間変形角応答特性, 日本建築学会構造系論文集, 第 75 巻, 第 649 号, pp. 567-575, 2013.3

9) Yasui, M., Nishikage, T., Mikami, T., Kamei, I., Suzuki, K. and Hayashi, Y.: Theoretical Solutions and Response Properties of Maximum Response of a Single-Degree-of-Freedom System for Pulse-Wave Ground Motions, Journal of Structural and Construction Engineering (Transactions of AIJ), Vol. 75, No. 650, pp. 731-739, 2010. 4 (in Japanese)

安井雅明, 西影武知, 三上知広, 亀井功, 鈴木恭平, 林康裕 : パルス性地 震動に対する 1 自由度系最大応答理論解と応答特性, 日本建築学会構造 系論文集，第 75 巻，第 650 号, pp. 731-739, 2010.4

10) Minami, H. and Hayashi, Y.: Response Characteristics Evaluation of Elastic 
Shear Beam for Pulse Waves, Journal of Structural and Construction Engineering (Transactions of AIJ), Vol. 78, No. 685, pp. 453-460, 2013. 3 (in Japanese) 南博之, 林康裕 : パルス波地動を受けるせん断棒の応答特性評価, 日本 建築学会構造系論文集, 第 78 巻, 第 685 号, pp. 453-460, 2013.3

11) Koyama, T., and Nagano, M.: Basic Research on Simplification of Pulsed Seismic Waves and Elasto-Plastic Response Characteristics, Proceeding of the Architectural Research Meetings I, Kanto Chapter, Architectural Institute of Japan, pp. 253-256, 2011. 3 (in Japanese)

小山哲夫，永野正行：パルス状の地震波の単純化と弾塑性応答特性に関 する基礎的研究，日本建築学会関東支部研究報告集 I, pp. 253-256, 2011.

12) Koyama, T., Hida, T. and Nagano, M.: Prediction of Etheroplastic Responses of Super High-Rise RC Building for Pulse-Wave Ground Motions, Proceeding of the Architectural Research Meetings I, Kanto Chapter, Architectural Institute of Japan, pp. 289-292, 2012. 3 (in Japanese)

小山哲夫, 肥田剛典, 永野正行: パルス波に対する超高層 RC 造建物の弾 塑性応答予測, 日本建築学会関東支部研究報告集 I , pp. 289-292, 2012.3

13) Vibration Analysis Models of Super High-rise RC Buildings Based on Database for Structural Design and Study on Nonlinear Response Characteristics to Pulselike Ground Motions, AIJ Journal of Technology and Design, Vol. 26, No. 64, pp. 881-886, 2020. 10 (in Japanese)

村田将一, 永野正行, 田沼毅彦, 小田聡: 超高層 $\mathrm{RC}$ 造建物の設計データ ベースに基づく振動解析モデルの構築とパルス性地震動入力に対する非 線形応答特性の分析, 日本建築学会技術報告集, 第 26 巻, 第 64 号, pp. 881-886, 2020. 10

14) Shigeyuki Okada: Study of the Evaluation of Seismic Casualty Risk Potential in Dwellings, Part1 Indoor-zoning map on dwelling space safety, Journal of Structural and Construction Engineering (Transaction of AIJ), No. 454, pp. 3949, 1993.12 (in Japanese)

岡田成幸：地震時の室内変容に伴う人的被害危険度評価に関する研究一 その 1 居住空間危険度マイクロゾーニングの提案一, 日本建築学会構造 系論文報告集，第 454 号，pp.39-49,1993. 12

15) Shigeyuki Okada: Study of the Evaluation of Seismic Casualty Risk Potential in Dwellings, Part2 Human behavior to evaluate during the 1993 Kushiro-oki earthquake, Journal of Structural and Construction Engineering (Transaction of AIJ), No. 481, pp. 27-36, 1996. 3 (in Japanese)

岡田成幸 : 地震時の室内変容に伴う人的被害危険度評価に関する研究一 その 21993 年釧路沖地震にみる摇れている最中の災害回避行動一, 日本 建築学会構造系論文集, 第 481 号, pp.27-36,1996. 3

16) Shigeyuki Okada and Nobuhiro Kuroda: Study of the Evaluation of Seismic Casualty Risk Potential in Dwellings, Part3 Diagnosis method for refuge route safety to outdoors, Journal of Structural and Construction Engineering (Transaction of AIJ), No. 563, pp. 83-89, 2003. 1 (in Japanese)

岡田成幸 : 地震時の室内変容に伴う人的被害危険度評価に関する研究一 その 3 室外一の避難脱出経路の危険度評価法の提案一, 日本建築学会構 造系論文集，第 563 号, pp. 83-89, 2003.1

17) Saburou Midorikawa and Takuma Saeki: Evaluation of Eartquake Injuries in Office Buildings, Journal of Structural and Construction Engineering (Transaction of AIJ), No. 476, pp. 49-56, 1995. 10 (in Japanese) 翠川三郎, 佐伯玩磨 : オフィスビル群における地震時の室内負傷者発生 予測，日本建築学会構造系論文集，第 476 号, pp. 49-56, 1995. 10

18) Hida, T., Ohno, A., Itoi, T., and Takada, T.: Construction of Seismic Response Analysis model of Human Body for Predicting Human Damage during Earthquake -Simulation Analysis Based on Shaking Table Test and Cart-type Inverted Pendulum model-, Journal of Structural and Construction Engineering (Transactions of AIJ), Vol. 84, No. 755, pp. 17-27, 2019. 1 (in Japanese) 肥田剛典, 大野敦史, 系井達哉, 高田毅士 : 地震時人的被害予測に向けた 人体の地震応答解析モデルの構築 振動台搭乗実験に基づく台車型倒立 振子モデルによるシミュレーション解析, 日本建築学会構造系論文集, 第 84 巻, 第 755 号, pp. 17-27, 2019.1

19) Hida, T., Ohno, A., Itoi, T. and Takada, T.: Development of Seismic Response Analysis Model of Human Body by Cart-Type Double Inverted Pendulum Model for Prediction of Human Injury during Earthquake, Journal of Structural and Construction Engineering (Transactions of AIJ), Vol. 84, No. 765, pp. 1377-1387, 2019. 11 (in Japanese)

肥田剛典, 大野敦史, 系井達哉, 高田毅士 : 地震時人的被害予測に向けた 台車型二重倒立振子による人体の地震応答解析モデルの構築, 日本建築 学会構造系論文集, 第 84 巻, 第 765 号, pp.1377-1387,2019.11

20) Ito, K., Hida, T., Itoi, T., and Takada, T.: Development of Evaluation Methodology of Human Injury During Earthquake Based on Seismic Response
Analysis Model of Human Body, Journal of Structural and Construction Engineering (Transactions of AIJ), Vol. 85, No. 767, pp. 159-168, 2020. 1 (in Japanese)

伊東一輝, 肥田剛典, 糸井達哉, 高田毅士: 人体の地震応答解析モデルに 基づく被震下人間負傷評価法の構築，日本建築学会構造系論文集，第 85 巻, 第 767 号, pp. 159-168, 2020. 1

21) Hida, T., Karatsu, H., Nagano, M., Itoi, T. and Takada, T.: Evaluation of Injury in Super High-rise Building During Earthquake Based on Nonlinear Seismic Response Analysis Model of Human Body, Journal of Structural and Construction Engineering (Transactions of AIJ), Vol. 85, No. 776, pp. 1263-1273, 2020. 10 (in Japanese)

肥田剛典, 唐津啓樹, 永野正行, 系井達哉, 高田毅士 : 人体の非線形地震 応答解析モデルに基づく超高層建物における地震時負傷評価, 日本建築 学会構造系論文集, 第 85 巻, 第 776 号, pp. 1263-1273, 2020. 10

22) Hinoura, Y., Nagano, M., Suzuki, K., Hida, T., Kitahori, T., Tanuma, T., and Oda, S.: Construction of Nonlinear Multi-degree-of-freedom System Models for Super High-rise Residential Buildings and Estimation of Seismic Responses During the 2016 Kumamoto Earthquake, Journal of Structural and Construction Engineering (Transactions of AIJ), Vol. 83, No. 749, pp. 963-973, 2018.7 (in Japanese)

日野浦雄高, 永野正行, 鈴木賢人, 肥田剛典, 北堀隆司, 田沼毅彦, 小田 聡: 超高層集合住宅を対象とした非線形多質点系モデルの構築と 2016 年熊本地震時の地震応答推定, 日本建築学会構造系論文集, 第 83 巻, 第 749 号, pp. 963-973, 2018. 7

23) Zhong, W. and Röck, H.: Energy and Passivity Based Control of the Double Inverted Pendulum on a Cart, Proceedings of the 2001 IEEE International Conference in Control Applications, pp. 896-901, 2001.

24) National Highway Traffic Safety Administration: Development of improved injury criteria for the assessment of advanced restraint systems-II, 1999.

25) Nakano, M., Matsumura, H., Tamagawa, M., Yamanaka, M., Yukimasa, T., and Kubota, M.: Theoretical Analysis of Head Injury Criterion (HIC), Journal of Biomedical Fuzzy Systems Association, Vol. 12, No. 2, pp. 57-63, 2010. (In Japanese)

中野正博, 松浦弘幸，玉川雅章，山中真，行正徹：頭部損傷基準值（HIC） の理論的分析, バイオメディカル・ファジィ・システム学会誌, Vol. 12, No. 2, pp. 57-63, 2010 .

26) Building Performance Standardization Association: Typical observed seismic waves, http://www.seinokyo.jp/jsh/top/ (accessed 2021.1.28) (in Japanese) 建築性能基準推進協会：代表的な観測地震波（加速度データ）, http://www.seinokyo.jp/jsh/top/（2021 年 1 月 28 日閲覧）

27) Hinoura, Y., Watanabe, S., Okano, K., Suzuki, K. and Nagano, M.: Indoor Damages of Super High-Rise Residential RC Buildings during the 2016 Kumamoto Earthquake (Part1 Comparison with Indoor Damages in Tokyo Metropolitan Area during the 2011 off the Pacific Coast of Tohoku Earthquake), Proceedings of the 12th Annual Meeting of Japan Association for earthquake Engineering, P3-11, 2016.9 (in Japanese) 日野浦雄高，渡辺眞伍，岡野一樹，鈴木賢人，永野正行：2016 年熊本地 震を対象としたアンケート調査に基づく超高層 $\mathrm{RC}$ 造集合住宅の室内被 害(その 13.11 本震時の首都圏との比較), 日本地震工学会第 12 回年次 大会梗概集, P3-11, 2016.9

28) Watanabe, S., Hinoura, Y., Okano, K., Suzuki, K. and Nagano, M.: Indoor Damages of Super High-Rise Residential RC Buildings during the 2016 Kumamoto Earthquake (Part1 Comparison between Kumamoto City, Kurume City and Fukuoka City), Proceedings of the 12th Annual Meeting of Japan Association for earthquake Engineering, P3-12, 2016.9 (in Japanese) 渡辺眞伍, 日野浦雄高, 岡野一樹, 鈴木賢人, 永野正行 : 2016 年熊本地 震を対象としたアンケート調査に基づく超高層 $\mathrm{RC}$ 造集合住宅の室内被 害(その 1 熊本, 久留米, 福岡の室内被害の比較), 日本地震工学会第 12 回年次大会梗概集，P3-12, 2016.9

29) Nagano, M., Tokunaga, D., Murata, M., Tamura, A., Kataoka, T. and Wang, X.: Shaking and Indoor Damages during the 2018 Osaka North Earthquake Based on Questionnaire Survey in Super High-Rise Residential Buildings, Summaries of Technical Papers of Annual Meeting, Architectural Institute of Japan, StructuresII, pp. 555-556, 2019.7 (in Japanese)

永野正行, 徳永大地, 村田正一, 田村彩女, 片岡卓也, 王欣 : アンケート 調査に基づく 2018 年大阪府北部地震時の超高層集合住宅の摇れと室内 被害, 日本建築学会大会学術講演梗概集, 構造- II, pp. 555-556, 2019.7 


\title{
EVALUATION OF HUMAN RESPONSES TOWARD INJURY PREDICTION IN SUPER HIGH-RISE RESIDENTIAL BUILDINGS EXCITED BY PULSE-LIKE GROUND MOTIONS
}

\author{
Hiroki KARATSU ${ }^{* 1}$, Takenori HIDA ${ }^{* 2}$ and Masayuki NAGANO*3 \\ ${ }^{1}$ JFE Civil Engineering \& Construction Corp. (Former, Tokyo University of Science) \\ ${ }^{2}$ Assoc. Prof., Graduate School of Science and Engineering, Ibaraki University, Dr.Eng. \\ ${ }^{3}$ Prof., Dept. of Architecture, Tokyo University of Science, Dr.Eng.
}

When a large pulse-like ground motion strikes in urban areas, significant structural damages may occur to super-highrise residential buildings along with human injuries or fatalities. Herein, to evaluate human injury, human responses were investigated in super-high-rise residential buildings using the Ricker wavelet as the pulse-like ground motion. Using nonlinear seismic response analysis models of super-high-rise RC buildings and those of the human body, the variation in the maximum displacement of the center of pressure $(\mathrm{CoP})$ and head velocity was examined based on the predominant periods and amplitude level of the input seismic waves. The following conclusions were drawn.

1) The maximum CoP displacement and head velocity of the human body in super-high-rise buildings excited using the Ricker wavelet tended to increase from the lower to the upper floors.

2) Diagrams were proposed for evaluating the maximum responses of the human body in super-high-rise buildings.

The Diagrams evaluated human responses using the maximum value of the pseudo-displacement response spectrum ( $p S d_{\max }$ ), maximum value of the pseudo-velocity response spectrum ( $\left.p S V_{\max }\right)$, and ratio of the predominant period of the input motion to the primary natural period of the building $\left(T_{\mathrm{p}} / T_{0}\right)$.

3) If the predominant period of the input motion matched the natural period of the building, humans can suffer a minor injury when $p S_{V_{\max }}=80(\mathrm{~cm} / \mathrm{s})$ and a fatal injury when $p S_{V_{\max }}=130(\mathrm{~cm} / \mathrm{s})$ at the building top floor.

4) As the maximum CoP displacement calculated using the human model was larger, the action difficulty became greater based on the questionnaire survey for the residents of super-high-rise residential buildings during an earthquake.

5) The maximum CoP displacement and head velocity of the human body obtained using the human model were compared with those obtained using the human body response evaluation diagram. The results obtained using the human model roughly corresponded to the evaluated values, thus confirming the validity of the human body response evaluation diagram. 